\title{
Age distribution of fossil landslides in the Tyrol (Austria) and its surrounding areas
}

\author{
C. Prager ${ }^{1,2}$, C. Zangerl ${ }^{1}$, G. Patzelt ${ }^{3}$, and R. Brandner ${ }^{4}$ \\ ${ }^{1}$ alpS Centre for Natural Hazard Management, Innsbruck, Austria \\ ${ }^{2}$ ILF Consulting Engineers, Rum b. Innsbruck, Austria \\ ${ }^{3}$ University of Innsbruck, former Institute for High Mountain Research, Austria \\ ${ }^{4}$ University of Innsbruck, Institute for Geology and Paleontology, Austria
}

Received: 20 December 2007 - Revised: 10 March 2008 - Accepted: 15 March 2008 - Published: 24 April 2008

\begin{abstract}
Some of the largest mass movements in the Alps cluster spatially in the Tyrol (Austria). Fault-related valley deepening and coalescence of brittle discontinuities structurally controlled the progressive failure and the kinematics of several slopes. To evaluate the spatial and temporal landslide distribution, a first comprehensive compilation of dated mass movements in the Eastern Alps has been made. At present, more than 480 different landslides in the Tyrol and its surrounding areas, including some 120 fossil events, are recorded in a GIS-linked geodatabase. These compiled data show a rather continuous temporal distribution of landslide activities, with (i) some peaks of activity in the early Holocene at about 10500-9400 cal BP and (ii) in the Tyrol a significant increase of deep-seated rockslides in the Subboreal at about 4200-3000 cal BP. The majority of Holocene mass movements were not directly triggered by deglaciation processes, but clearly took a preparation of some 1000 years, after ice withdrawal, until slopes collapsed. In view of this, several processes that may promote rock strength degradation are discussed. After the Late-Glacial, slope stabilities were affected by stress redistribution and by subcritical crack growth. Fracture propagating processes may have been favoured by glacial loading and unloading, by earthquakes and by pore pressure fluctuations. Repeated dynamic loading, even if at subcritical energy levels, initiates brittle fracture propagation and thus substantially promotes slope instabilities. Compiled age dating shows that several landslides in the Tyrol coincide temporally with the progradation of some larger debris flows in the nearby main valleys and, partially, with glacier advances in the Austrian Central Alps, indicating climatic phases of increased water supply. This gives evidence of elevated pore pressures within the intensely fractured rock masses. As a result, deep-seated gravitational
\end{abstract}

Correspondence to: C. Prager (prager@alps-gmbh.com) slope deformations are induced by complex and polyphase interactions of lithological and structural parameters, morphological changes, subcritical fracture propagation, variable seismic activity and climatically controlled groundwater flows.

\section{Introduction}

The Quaternary valley evolution in the Tyrolean Alps (Austria) is characterised by the occurrence of several deep-seated mass movements, the velocities of which range from slowly creeping landslides to catastrophic rockslides and rockfalls. Based on morphological and lithostratigraphical field criteria, the ages of failure initiation have long been subject to intense debate. Generally, late-Pleistocene glacier withdrawal, causing an unbalanced relief and thus increasing the stresses within the over-steepened slopes (cf. Ballantyne, 2002; Cossart et al., 2008), was assumed to be the most dominant landslide trigger. In addition, many rockslide deposits in the Alps are characterised by pronounced moraine-like debris ridges and are occasionally covered by relicts of Pleistocene fluvioglacial deposits. Since both features were believed to indicate a contact with late-glacial ice, and since some events accumulated on glacial till, many landslides were simply categorised as late-glacial to early post-glacial events (e.g. Abele, 1969, 1974; Seijmonsbergen et al., 2005).

But in the majority of cases, radiometric dating of landslides in the Alps clearly yielded Holocene ages of failure, indicating that slope failures were not directly controlled by deglaciation processes. One of the first mass movements dated in the Alps is the Molveno rockslide (Trentino, Italy), featuring a Holocene age of about $2908{ }^{14} \mathrm{C}$ yrs BP (Abele, 1974). Also the largest Alpine mass movement in metamorphic bedrock units, the prominent Köfels rockslide (Tyrol, Austria), was dated as an early post-glacial event at around $8710{ }^{14} \mathrm{C}$ yrs BP (Heuberger, 1966). Regardless of these case

Published by Copernicus Publications on behalf of the European Geosciences Union. 


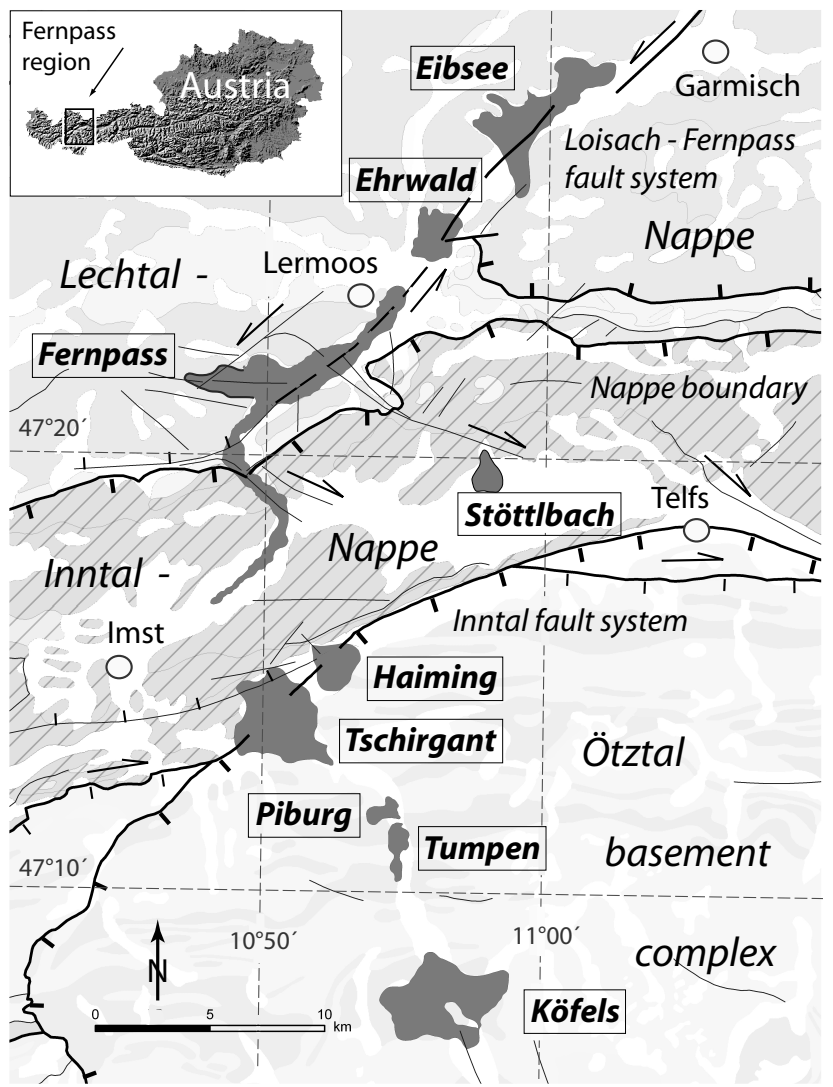

Fig. 1. Main geological structures of the Fernpass region (Tyrol, Austria) showing thrust sheet units of the Northern Calcareous Alps (Lechtal- and Inntal-Nappe), the Ötztal Basement complex (Brandner, 1980, modified) and deep-seated rockslide deposits (shaded dark grey).

studies, only further dating of mass movements in the Eastern Alps, especially in the 1990's, caused a definitive change of the paradigm, according to which late-glacial ice withdrawal should have triggered slope collapses (see also discussions by Abele, 1997a; Poschinger, 2002). Based on further investigations, a dependency of Holocene landslide-activities on climatic fluctuations was assumed (e.g. Raetzo-Brülhart, 1997; Matthews et al., 1997; Dapples et al., 2003; Soldati et al., 2004).

This paper deals with the temporal distribution of dated mass movements in the Tyrol (Austria) and its surrounding areas. Here, several deep-seated landslides rank among the largest events in the Alps and show a close spatial distribution. One of them, the Holocene Fernpass rockslide, was recently dated and was found to form a temporal cluster with its adjacent mass movements (Prager et al., 2006a, 2007). Also current field studies (Prager et al., 2006b, 2006c; Zangerl et al., 2007, 2008) yielded evidence that both the unsmoothed rough scarps and the morphologically structured accumulation areas of many landslides were not glacially overprinted and thus not directly induced by Late-Pleistocene glacier fluctuations. In view of these facts, a first comprehensive compilation of dated mass movements in the Eastern Alps has been made. It provides insights into potential causes and rock strength-degrading mechanisms that may have favoured slope failures during the Holocene.

\section{Geological setting}

The Eastern Alps are made up of complex fold and thrust belts of different nappe units, which were deformed polyphasically and heteroaxially. The main geological structures were formed by Cretaceous to Tertiary thrust and extension tectonics (Eisbacher and Brandner, 1995; Schmid et al., 2004). In the Tyrol, the majority of the dated mass movements are situated in the polymetamorphic Ötztal basement complex and in detached Mesozoic cover units of the Northern Calcareous Alps. Rock units affected by rapid failure events are here predominantly competent orthogneisses, amphibolites and thick carbonate successions such as the Wetterstein and Hauptdolomit Formation (both Triassic). Incompetent bedrock units, e.g. paragneisses, phyllites and marlrich successions, are generally characterised by lower slope deformation rates of some centimetres to metres per year.

Recent field studies at several unstable slopes in the Tyrol and at adjacent sites yielded evidence that fault-related valley deepening and the coalescence of brittle discontinuities control progressive failure and landslide kinematics (see Sect. 4). Intensive cataclasis along large-scale brittle fracture zones as the prominent Inntal and Loisach fault systems (Fig. 1) enabled substantial fluvio-glacial erosion and valley deepening. This morphological change caused stress redistribution of the valley slopes and uncovered favourably oriented sliding planes.

\section{Data compilation}

To evaluate the spatial and temporal distribution of landslides in the Eastern Alps, a GIS-linked geodatabase has been set up. At present this includes various data of more than 480 different mass movements in the Tyrol and its surroundings, ranging from late-glacial to modern failure ages. Out of these, approx. 220 events feature unknown ages of failures and/or unknown activities. About 140 post-medieval to recently active landslides were compiled for the Tyrol but not considered in this study. Dated fossil (i.e. pre-historic and ancient historic) mass movements from adjacent areas such as southern Germany, northern Italy and eastern Switzerland were also included and presently comprise about 120 events. These are about 60 debris flows and about 60 rock slope failures, which are mainly rapid events such as rockfalls and rockslides. Slow slope-movements, characterised by deformation rates of millimetres to metres per year, can hardly be dated as representative single-events, but rather reflect activities over certain time spans ("rock slope failures" in general 
with a "range" of activities, see Table A1). This may also be the case for debris flows, but compiled data (Hübl, 1995) and detailed site investigations (e.g. Irmler, 2003; Weber, 2003) yielded evidence that larger debris fans are characterised by pulsed, precipitation-controlled activities of several sub-events. Dated debris flows have been compiled in this landslides-study because i) Cruden (1991), Cruden and Varnes (1996) and the UNESCO Working Party on World Landslide Inventory define landslides as "a movement of a mass of rock, earth and debris down a slope" and ii) because debris flows may yield information on paleo-climatic conditions.

Age determination of landslides is, most commonly, carried out by ${ }^{14} \mathrm{C}$-dating of organic remnants that are present in sediments overridden by the mass movement (maximum age of the event), and/or are entrapped within the landslide debris (proxy for event age), and/or accumulated in landslidedammed backwater deposits or lakes situated atop the mass movement (minimum age of the event). In the majority of cases, not the rock slope failure itself has been used for dating but material underlying and/or overlying the failed rock masses. Thereby, the time-lag between failure event and accumulation of the dated material can hardly be quantified. In view of this and because the exact stratigraphic relation between landslide deposits and dated samples is often poorly documented in the available data sources, some compiled data of this paper provide only indirect information about the age of fossil mass movements. Concerning the basic data quality, some events such as younger and larger mass movements may be over-emphasized due to outcrop conditions, sampling bias, inhomogeneities of records and statistical errors.

However, the available radiocarbon laboratory dates of ${ }^{14} \mathrm{C}$-dated mass movements were calibrated to calendar dates (quoted $0 \mathrm{BP}=1950 \mathrm{AD}$ ) using the OxCal software version 3.10 (Bronk Ramsey, 2005) and its implemented calibration curve IntCal04. The ranges of the arithmetic mean ages are based on the statistical 2- $\sigma$ standard deviation (corresponding to $95.4 \%$ probability). For mass movements featuring more than one dated sample, a mean and its standard deviation was calculated by applying the Gaussian error propagation law for linear cases on to the individual sample dating. For some roughly or indirectly dated events, the ranges of standard deviations had to be estimated in order not to lose any information, when visualised in graphs. To ensure proper comprehensibility, all compiled data including references have been included in the Appendix (Table A1).

\section{Geology and ages of selected landslides}

Some of the largest fossil mass movement deposits in the Alps cluster spatially in the Fernpass - northern Ötz valley region (Tyrol, Austria). In an area of less than $40 \times 20 \mathrm{~km}$, at least 13 individual failure events are encountered which in- clude the prominent Eibsee, Fernpass, Tschirgant, Tumpen and Köfels rockslides (Sect. 4.1 to 4.8, Fig. 1). Deep-seated rock slope failures that have been radiometrically dated are also encountered nearby at Gepatsch/Hochmais (Kauner valley; Sect. 4.9) and, further away, at Pletzachkogel (Inn valley; Sect. 4.10). Scarp structures, run-out paths and sedimentary fabrics of these landslides indicate, in the majority of cases, rapid failure event such as rock slides and rock avalanches (Sturzströme).

\subsection{Eibsee rockslide}

Close to the Tyrolean-Bavarian border, the Eibsee rockslide (Fig. 1) broke off the north-face of the Zugspitze massif $(2961 \mathrm{~m})$, the highest mountain in Germany, and mobilized about 400-600 million $\mathrm{m}^{3}$ of accumulated debris (Abele, 1974; Golas, 1996). It originated from a subvertical cliff, which is several hundred metres high and built up by mainly well-bedded Triassic carbonates of the Muschelkalk Group (Anisian) and the Wetterstein Formation (Ladinian-Carnian). The latter, a main rock unit of the Northern Calcareous Alps, comprises here stacked limestones of lagoonal cycles up to $1000 \mathrm{~m}$ in thickness. Due to Paleogene compression, this competent Triassic platform was thrust over several hundred metre thick, incompetent Jurassic-Cretaceous limestones and marls. Structurally the Zugspitze massif features an open first-order syncline with a fold axes dipping moderately to the east (Eisbacher and Brandner, 1995). Therefore, the discontinuities which were of relevance for the Eibsee rockslide were not the bedding planes, dipping moderately SE into the slope, but the NW- and above all the NE-trending subvertical fault and fracture systems. Some of these separation planes are intersected by tunnels of the German rack railway to the Zugspitze and exhibit openings of several metres which occasionally extend to the surface (Knauer, 1933). Field evidence of intense brittle faulting can be observed at the NW-face of the Zugspitze, where NE-SW-striking, subvertical faults and associated discontinuities are part of the large-scale sinistral Loisach shear system (Fig. 1). This system caused deepseated intensive fracturing of the folded carbonates and isolated blocks in precipitous rock walls. The resulting slope kinematics, favoured by the lithological conditions of the Zugspitze massif, i.e. competent carbonates resting upon incompetent rock units, was characterised by a combination of rock spread processes (Cruden and Varnes, 1996) and steppath failures with internal shearing.

Based on morphological field criteria, the Eibsee rockslide deposits were formerly interpreted as a "late-glacial rockslide-moraine" (Vidal, 1953), but several wood samples gained in drillings yielded a mean age of around 3700 ${ }^{14} \mathrm{C}$ yrs BP (Jerz and Poschinger, 1995). Six samples of similar age, which were presumably not redeposited, were calibrated to calendar years and show an arithmetic mean age of $4181 \pm 627 \mathrm{cal}$ BP. Based on the age of the youngest 


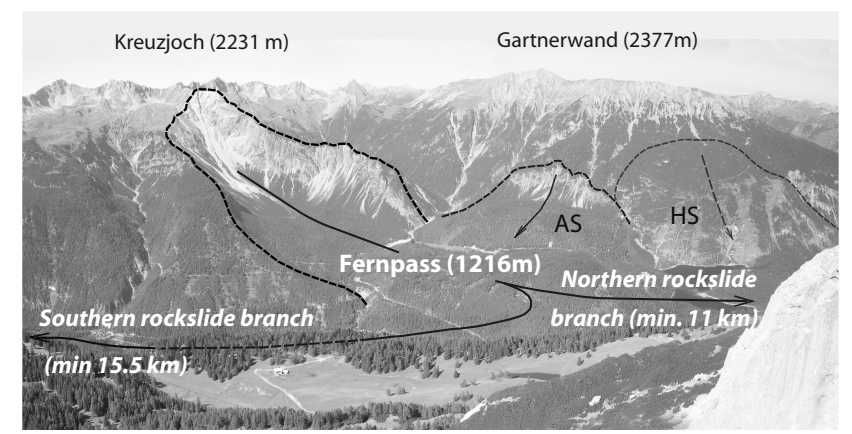

Fig. 2. View towards northwest to the wedge-shaped scarp of the Fernpass rockslide and its associated mass movements (rockslide "Am Saum" AS, instable slope "Hohler Stein" HS).

wood fragment, the Eibsee event has a minimum age of $3935 \pm 215$ cal BP (Table A1).

\subsection{Ehrwald rockslide}

At the western base of the Zugspitze massif, the carbonate Ehrwald rockslide deposits cover an area of about $2 \mathrm{~km}^{2}$ and an average run-out distance of about $3.5 \mathrm{~km}$ (Abele, 1974 including references). Assuming a thickness of about 5$20 \mathrm{~m}$, the accumulated volume varies about some 10-40 million $\mathrm{m}^{3}$. The lithological and structural predisposition corresponds with that of the adjacent Eibsee rockslide, i.e. both failures were clearly controlled by brittle faulting along the NE-orientated Loisach fault system (Fig. 1).

The Ehrwald deposits form a scenic hilly landscape with several pronounced ridges and, thus, were morphologically classified as "late-glacial rockslide moraine" (Abele, 1964, 1974). But the internal structure of these sediments, which so far have not been dated radiometrically, is characterised by an unstratified, coarsening-upward facies with several shattered clasts featuring a jig-saw-fit of grain-boundaries. These sedimentary features have not been observed in glacially derived deposits and may only be attributed to dynamically disintegrated rockslide masses. This and the lack of Quaternary cover as well as the absence of glacial smoothing of the topography suggest a Holocene age for the Ehrwald rockslide.

\subsection{Fernpass rockslide}

The Fernpass rockslide in the western Northern Calcareous Alps is characterised by two channelled Sturzstrom branches, which contain a rock mass volume of about $1 \mathrm{~km}^{3}$ and cover excess run-out distances up to at least 10.8 and $15.5 \mathrm{~km}$ respectively. This large-scale event was followed by a smaller rockslide of unknown age and the development of a deeply fractured slope that has not yet failed (Fig. 2).

The rockslide debris originated from a well exposed and exceptionally deeply incised niche, which is made up of platy dolomites, limestones and marls of the several hundred metre thick Seefeld Formation (Norian, Upper Triassic). Polyphase and heteroaxial deformations generated fold and fracture systems of varying orientation (Eisbacher and Brandner, 1995). Thus, the failure zones of the Fernpass rockslide and of its juxtaposed slopes developed by the stepwise coalescence of brittle discontinuities. Both the lithological predisposition and the complex brittle deformations define the sliding planes as well as the block-size distributions of the rockslide debris.

Field data and results of hybrid seismic measurements near the apex of the present Fernpass point to a deep-seated cataclasis along the NE-orientated Loisach-Fernpass fault system (Fig. 1). This indicates a steep pre-failure topography of the valley flanks and a fluvio-glacially undercut toe of the slope. Here the top of the bedrock is covered by approx. 500$600 \mathrm{~m}$ thick soft rock deposits, which decrease significantly in thickness laterally and are assumed to originate mainly from the Fernpass rockslide (Prager et al., unpubl. data). Due to the oblique impact of the sliding rock masses against the opposite mountain slope, they were proximally piled up as a remarkably thick debris ridge and split into two Sturzstrom branches. Their run-out was favoured by the large rockslide volume, channelling effects in the narrow valley, dynamic disintegration and, crucially, by an undrained dynamic loading of the water-saturated substrate (Prager et al., 2006b, 2006c).

Formerly, morphological and lithostratigraphical field criteria, such as moraine-like debris ridges, funnel-shaped "dead-ice" sink holes and the spatial distribution of Pleistocene cover rocks, were used to differentiate between a lateglacial main event and a succeeding post-glacial collapse (Abele, 1964, 1974). But now field investigations show that neither the rough scarp nor the intensely structured accumulation area features any signs of a smooth morphology, which speaks against glacial overprinting.

This field evidence was confirmed by the application of three different radiometric dating methods on individual sampling sites (Prager et al., 2006a, in press). Close to the scarp area, rockslide-dammed torrent deposits yielded a ${ }^{14} \mathrm{C}$ minimum age of $3380-3080 \mathrm{cal}$ BP. So far, the chronostratigraphic base of this at least $15 \mathrm{~m}$ thick backwater sequence has not yet been dated. However, two cosmogenic radionuclide ${ }^{36} \mathrm{Cl}$ exposure ages of large-scale sliding planes at the scarp, where the sampled platy dolomites indicate a mean age of $4100 \pm 1300 \mathrm{yrs}$ for the failure event. Further data were gained from the curiously, strongly deflected southern rockslide branch, where post-depositional carbonate cements are encountered. They were dated using the ${ }^{230} \mathrm{Th} /{ }^{234} \mathrm{U}$-disequilibrium method and yielded a minimum age of $4150 \pm 100 \mathrm{yrs}$ for the accumulation of the rockslide debris (Ostermann et al., 2007). Based on these data, a temporal differentiation between two failure events, one making up the northern rockslide branch, and another, making up the southern branch, is not yet possible. All dates coincide well and indicate that the Fernpass rockslide occurred $4200-4100$ yrs ago. 


\subsection{Tschirgant rockslide}

From the steep and rugged Tschirgant massif $(2370 \mathrm{~m})$, two deep-seated rockslides travelled down to the river Inn at approx. $700 \mathrm{~m}$ a.s.l.: the prominent Tschirgant rockslide (180-240 million $\mathrm{m}^{3}$; Abele, 1974) in the southwest and the smaller Haiming rockslide (see Sect. 4.5) in the northeast (Figs. 1, 3). Both slope failures are encountered at the structurally complex southern margin of the Inntal thrust sheet (Northern Calcareous Alps), which in this area is made up of folded and faulted Middle- to Upper-Triassic carbonates (Eisbacher and Brandner, 1995). Brittle deformation and deep-seated cataclasis associated with the NE-trending Inntal fault system enabled a substantial fluvio-glacial deepening of the Inn valley between the Northern Calcareous Alps and the southerly adjacent Ötztal basement unit.

The widely and deeply fractured scarp area of the Tschirgant rockslide, also referred to as "Weißwand", is mainly composed of obscurely bedded dolomites and limestones of the Wetterstein Formation (Ladinian-Carnian), here predominantly featuring reef- and peri-reef facies, and by well-bedded carbonates, siliciclastics and evaporites (Rauhwacken) of the Raibl Group (Carnain). Structurally, the scarp area is characterised by intensely folded and faulted bedrock units. Due to thrust tectonics and the resulting nappe-piling (Pagliarini, in preparation), the sediments of the Raibl Group are encountered at both the hanging wall and the foot wall of the Wetterstein-Formation, i.e. at the top and the toe of the slope. As a result of the polyphase and heteroaxial deformation, the slope failure was controlled by a step-wise coalescence of NE-trending, frequently overturned, bedding and fault planes with NW-trending dextral fracture systems. In the scarp area, the competent carbonates of the Wetterstein Formation exhibit bedding planes and several extensive fracture systems, which dip out of the slope and form preferably oriented sliding planes. The slope collapse was furthermore favoured by karst structures in the Wetterstein Formation and by the occurrence of Rauhwacken with a thickness of several tens of metres at the toe of the slope. In the Tschirgant area, some intensely mineralised springs are a sign of hydrochemical evaporite leaching. In the long run, this process could have led to increased bedrock porosities and to a reduced thickness of the evaporite strata, which would have resulted in gravitational deformations of the brittle dolomites in hanging wall position.

The descending Tschirgant rockslide buried the Inn valley and entered the mouth of the northern Ötz valley, where the contact of basal slide deposits and their substrate are naturally exposed. These contact zones display a complex geometry, where in the course of the rockslide event presumably water-saturated valley floor sediments were injected into the rockslide masses filling up steep extension structures (Patzelt and Poscher, 1993; Abele, 1997b) and where diamicts were created by a mingling with the rockslide. The undrained loading of the substrate caused a consider-

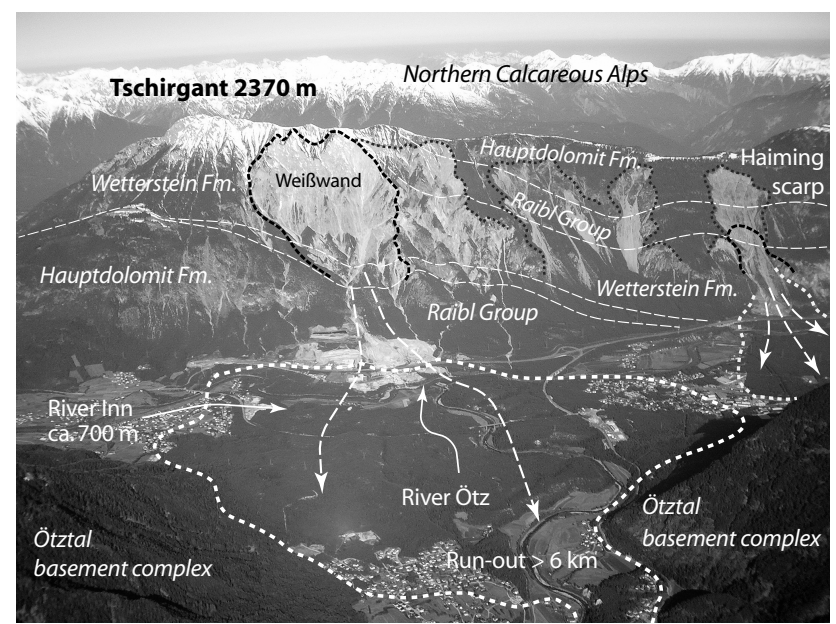

Fig. 3. Oblique view to the northern Ötz- and Inn-valley: scarp (black stippled) and accumulation areas (white stippled) of the Tschirgant and Haiming rockslides (photo courtesy of M. Schuster 2007).

able run-out of approx. $6.2 \mathrm{~km}$ (Fig. 3) and a travel angle ("Fahrböschungswinkel") of about $13^{\circ}$.

Based on morphological and lithostratigraphical criteria, Heuberger (1975) assumed an interaction of the carbonate Tschirgant rockslide with late-glacial Ötztal ice, but radiometric dating established a coherent Holocene age of around $2900{ }^{14} \mathrm{C}$ yrs BP (1050 cal BC; Patzelt and Poscher, 1993) for the main event. Further investigations showed evidence that the widespread Tschirgant deposits were made up by at least two failure events, which occurred at $3753 \pm 191$ cal BP and at $3151 \pm 191$ cal BP (Patzelt, 2004a).

\subsection{Haiming rockslide}

About three kilometres northeast of the Tschirgant scarp, the Inn valley floor is covered by of $25-34$ million $\mathrm{m}^{3}$ (Abele, 1974) relatively finely-ground carbonate deposits of the Haiming rockslide (Fig. 3). The average thickness is assumed to be about 5-20 m, with some local maxima being approx. $40 \mathrm{~m}$. At the unusually rough and stepped, wedgeshaped scarp the bedding planes dip into the slope and no distinct large-scale sliding planes are observable. This indicates that the failure was clearly structurally controlled by the complex coalescence of differentially orientated and densely, i.e. meter-size, spaced discontinuities.

The accumulated debris, i.e. karstified and often brecciated dolomites of the topmost Wetterstein Fm (M- to UTriassic), indicates that the main slide detached from lower parts of the slope. It covers a run-out length of about $2.5 \mathrm{~km}$ and features a low run-out travel angle of about $11^{\circ}$. The exposure of higher regions of the present-day scarp, which show a several hundred metre thick, well-bedded succession of the lithologically inhomogeneous Raibl Group and 


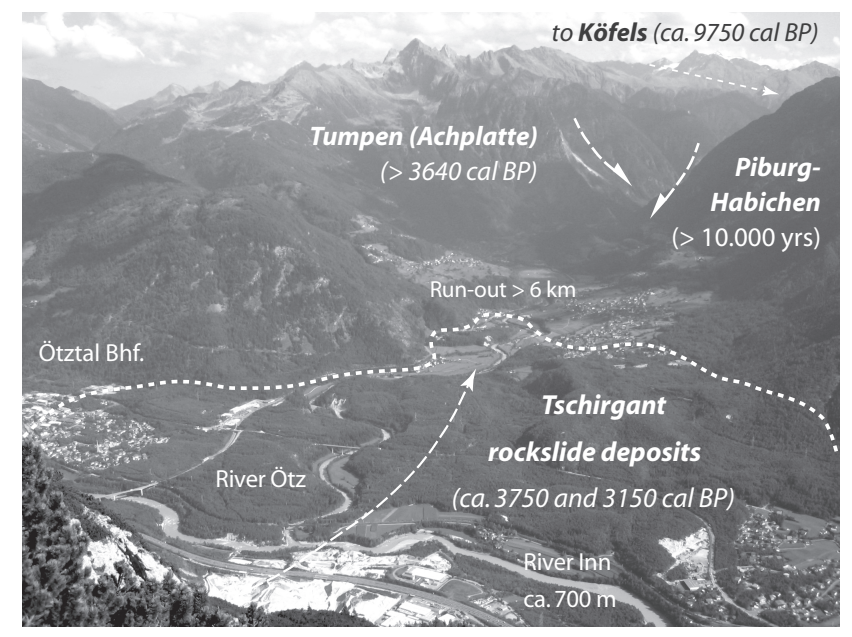

Fig. 4. View from the Tschirgant massif (Northern Calcareous Alps) towards southeast to the rockslide deposits and adjacent scarp areas in the northern Ötztal basement complex.

the Hauptdolomit Formation (both U-Triassic), may be attributed to secondary erosion processes such as rockfalls and debris slides.

Based on field surveys and several radiocarbon dates, Patzelt (2004a) differentiated three failure events, which occurred at $3535 \pm 95$ and at $3065 \pm 145 \mathrm{cal}$ BP plus a smaller rockfall event at $1680 \pm 140 \mathrm{cal} \mathrm{BP}$ (Table A1).

\subsection{Stöttlbach landslide}

About $10 \mathrm{~km}$ to the northeast of the Haiming scarp, the Stöttlbach landslide deposits (Fig. 1) form an approx. $2.8 \mathrm{~km}^{2}$ wide lobe and cover a run-out distance of about $4.5 \mathrm{~km}$. Its average thickness strongly varies between approx. $5-35 \mathrm{~m}$ and the mean volume most probably ranges from 20-30 million $\mathrm{m}^{3}$. The debris is made up of limestones of the Wetterstein Group (M- to U-Triassic), with only a few siliciclastic components of the Raibl Group (U-Triassic) involved. These hummocky-shaped deposits were formerly interpreted as glacially derived moraines, but have recently been dated. Preliminary ${ }^{36} \mathrm{Cl}$ exposure ages of limestone boulders of the Wetterstein Group indicate a failure event in the range of 3.5-4 ky (Kerschner and Ivy-Ochs, personal communication 2006; Westreicher, in press).

\subsection{Piburg-Tumpen rockslides}

The N-trending Ötz valley, one of the main side valleys of the Inn valley, is deeply incised in the metamorphic Ötztal basement complex. Its Quaternary valley filling is characterised by significant valley steps and flat upstream valley floors, which genetically may be attributed to multi-phase landslide events and thus to associated backwater sediments (Heuberger, 1975 including references). Due to these on- lapping sediments, estimations of the volumes and run-out distances of the rockslide events are here hardly possible.

The Piburg and Habichen rockslide deposits (Figs. 1, 4), which are both situated close to the distal deposits of the Tschirgant rockslide, dammed the southern edge of Lake Piburg. ${ }^{14} \mathrm{C}$ analyses on lacustrine deposits, gained from drillings in the central part of the lake, yielded an age of at least $11500 \mathrm{cal} \mathrm{BP}$ for the onset of the sedimentation (Wahlmüller, unpubl. data) and indicate a similar minimum age for the Piburg rockslide barrier.

In the southerly adjacent Tumpen area, sinkhole collapses in rockslide-dammed backwater sediments have repeatedly been documented over the last 300 years and have led to extensive ground reconnaissance surveys. According to these surveys, a differentiation is to be made in this area between at least four different slide masses, which were transgressed by at least two fluvio-lacustrine deposition sequences with a minimum total thickness of $60 \mathrm{~m}$. The younger succession provided a minimum age of about $3380 \pm 80{ }^{14} \mathrm{C}$ yrs BP (Poscher and Patzelt, 2000), i.e. $3640 \pm 200 \mathrm{cal}$ BP, for the damming rockslide event. Depth extrapolations of the existing dating results suggest that the older sequence and its rockslide barrier date to about 6000 cal BP (Patzelt, personal communication).

\subsection{Köfels rockslide}

To the south, the Tumpen backwater deposits border on the largest Alpine mass movements in metamorphic bedrocks, the famous Köfels rockslide. The failing bedrock units, predominantly granitic augen- and flaser-gneisses and some paragneisses, detached from an east-facing slope and buried both the Ötz valley and the opposing mouth of the Horlach valley (Fig. 5). The several hundred metre thick rockslide debris blocked the river Ötz and caused the accumulation of the up to $100 \mathrm{~m}$ thick fluvio-lacustrine backwater deposits of the Längenfeld basin (Heuberger, 1966, 1975). According to reflection seismic measurements, the top of the compact bedrock units plunges from approx. $50-80 \mathrm{~m}$ below ground in the Längenfeld basin steeply northwards to approx. $400 \mathrm{~m}$ below ground at the paleo-slope toe. This significant valleystep presumably caused substantial stress concentrations at the toe of the slope and thus favoured the massive failed volume of about $3.2 \mathrm{~km}^{3}$ (Brückl et al., 2001). These data and the presence of preferably orientated, east-dipping sliding planes, which are encountered between the village of Köfels and the present-day head-scarp, clearly point to a structural predisposition of this large-scale rock slope collapse.

Radiocarbon dating of buried wood and surface exposure dating of rockslide boulders (Ivy-Ochs et al., 1998), morphological features (Hermanns et al., 2006) and the spatial distribution of ortho- and paragneissic rockslide debris in the Köfels area indicate that a well established major slide event occurred in the early Holocene at about $9800 \mathrm{cal}$ BP and was succeeded by at least one secondary rockslide event (Fig. 5). 


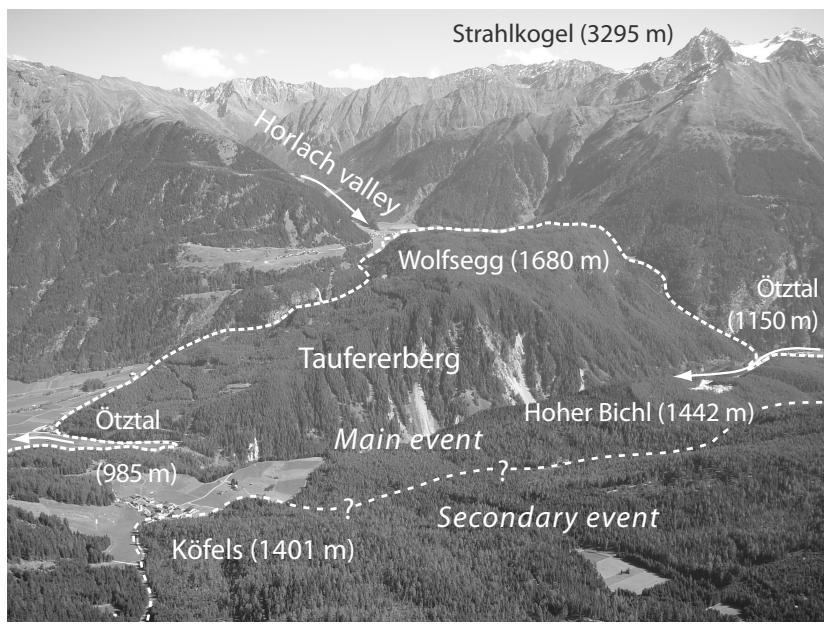

Fig. 5. View from the Köfels headscarp towards East to the widespread and thick rockslide deposits.

\subsection{Hochmais rockslide}

Approx. $20 \mathrm{~km}$ southwest of Köfels, both flanks of the upper Kauner valley have been affected by deep-seated rock slope deformations. Due to the construction of a hydropower plant reservoir near the toe of these slopes, detailed field surveys, drilling campaigns, geodetic-, seismic- and InSAR-measurements were carried out and yielded evidence of the geometry, structure and long-term slope-behaviour (Tentschert, 1998 and references therein). According to these findings, the deep-seated Atemkopf-Hochmais creeping landslide, which is situated at an east-facing slope in folded and jointed paragneisses, comprises an area of about $2.8 \mathrm{~km}^{2}$ and a volume of about 300 million $\mathrm{m}^{3}$. Lower parts of the slope, i.e. the Hochmais rockslide, failed post-glacially and slid over $400 \mathrm{~m}$ on top of till and talus deposits. Within these till deposits, intersected at depth by an investigation adit, a significant $4-5 \mathrm{~m}$ thick sliding zone is encountered (Brückl et al., 2004; Zangerl et al., 2007).

Extensive drilling campaigns at the lowermost slope areas and in the former valley floor, now flooded by the Gepatsch hydropower reservoir, revealed wood-bearing sands and gravels, which both underlie and lap-on the displaced Hochmais slab. At the slope toe, the solid bedrock units are overlain firstly by a $26 \mathrm{~m}$ thick succession of sands and gravels, with wood-findings near the top, secondly by $4 \mathrm{~m}$ thick till deposits and thirdly by the at least $30 \mathrm{~m}$ thick Hochmais slab. These wood fragments yielded a maximum age for the rockslide of $7210 \pm 140$ BC, i.e. $9160 \pm 150$ cal BP. A minimum age of $6340 \mathrm{BC}$ (i.e. $8295 \pm 105 \mathrm{cal}$ BP) was provided by other wood-bearing sands and gravels, which lap-on the Hochmais slab (Schmidegg, 1966). Considering the $2 \sigma$ standard deviations of these dated samples, the Hochmais rockslide occurred between 9310 and $8190 \mathrm{cal} \mathrm{BP}$, at about the arithmetic mean of $8750 \pm 560$ cal BP (Table A1).

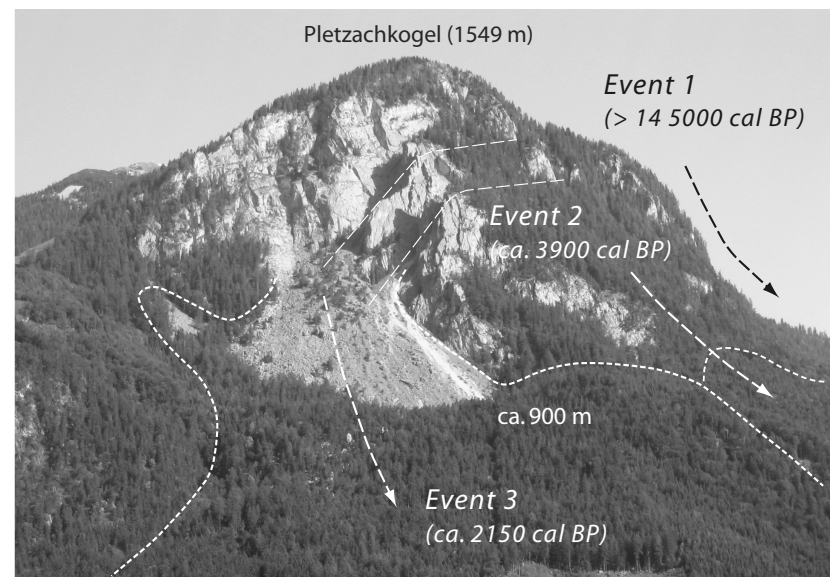

Fig. 6. Pletzachkogel south- and southeast-face showing brittle fracture systems and scarp areas of three dated failure events.

\subsection{Pletzachkogel rockslides}

The Pletzachkogel in the Lower Inn valley is a steep southand east-facing rock slope (Fig. 6), with $>80$ million $\mathrm{m}^{3}$ (Abele, 1974) of spatially complex distributed rockslide deposits at its base. The scarp region consists of a succession of Jurassic breccias, which is several hundred metres thick and contains characteristic red internal sediments. These competent rocks overly limestones of the Oberrhätkalk as well as limestones and marls of the incompetent Kössen Formation (both Upper Triassic). Comparable to the Tschirgant massif (Fig. 3), the Pletzachkogel scarp is situated at the southern margin of the Northern Calcareous Alps and thus also affected by deep-seated brittle fracture zones. Especially faulting along the Inntal fault system caused a substantial rock fragmentation and generated NE-trending discontinuities with moderate to steep down slope dips.

Based on morphological criteria and the spatial distribution of the accumulated debris, three failure events originating from different source areas are to be differentiated (Fig. 6). The youngest of these events was a highly mobile rock avalanche (Sturzstrom), which travelled from a well-exposed scarp down to the river Inn, covering a runout distance of approx. $3.5 \mathrm{~km}$ and a run-out travel angle of $15^{\circ}$. Detailed field investigations and numerous radiocarbon dating clearly indicate that the Pletzachkogel rockslides occurred firstly in the Late-Glacial, secondly in the middle Holocene at about 3910 and thirdly at about 1735 cal BP (Patzelt, 2004b; Table A1). At least one minor rockfall event occurred in the 20th century.

\section{Seismicity of the Fernpass region}

In the Fernpass region, some of the largest rockslides in the Alps not only cluster spatially but also show similar ages of failure. In addition, this region as well as some major 
fault zones nearby, e.g. close to the NE- trending Inntal and Engadin Line, show increased earthquake activity (Drimmel, 1980; Reiter et al., 2003). Earthquake-related slope instabilities in different geological settings have been inferred by several (paleo-)seimological studies (e.g. Keefer, 1984; Jibson, 1996; Becker et al., 2005; Monecke et al., 2006). In view of these findings, and with the objective of studying possible predisposing and (paleo-)trigger mechanisms, the recent seismicity of the Fernpass region was evaluated.

Close to the Fernpass, epicentral foci at the villages of Nassereith and Namlos (Schorn, 1911, 1922; Kraus, 1931; Fig. 7) show clear evidence of neotectonic movements. Some strong earthquakes with magnitudes $\mathrm{M} \leq 5.3$ and EMS-98 epicentral intensities $I_{0} \leq 7.5^{\circ}$ MSK rank here among the most intense ones ever measured in Austria (Table 1; Drimmel, 1980). One of these major events occurred in 1930 a few kilometres west of the Fernpass, near the small village of Namlos. At least 16 main shocks and numerous aftershocks were recorded and subjectively registered even at distances of about $200-400 \mathrm{~km}$. Locally, this earthquake changed the hydraulic flow field by dislocating springs, it opened ground clefts and triggered several rockfall events nearby (Klebelsberg, 1930).

Compiled earthquake data indicate, that, in western Austria, the effective horizontal ground acceleration shows significant maxima of about $1 \mathrm{~m} / \mathrm{s}^{2}$ in the middle Inn valley and the Fernpass region (ÖNORM B4015, 2007). With respect to the latter, the available earthquake records show:

- Strong intensities: several severe shocks with magnitudes $\mathrm{M} \leq 5.3$ and epicentral intensities $I_{0} \leq 7.5^{\circ} \mathrm{MSK}$ are spatially clustered in the Lechtal Alps and are among the most intense ever measured in Austria (Table 1). For one of these major events, a focal depth of $8 \mathrm{~km}$ was determined macroseismically (Franke and Gutdeutsch, 1973), which - when projected into a structural transect - points to active tectonics somewhere below the base of the Northern Calcareous Alps (Eisbacher et al., 1990).

- Swarm-like earthquakes: here characteristic sequences of earthquakes without significant fore- and aftershocks cluster both in time and space. These events, e.g. those registered in May and June 2005, were characterised by low to moderate magnitudes $M=1.3-3.0$ but clearly felt with epicentral intensities of $I_{0}=3-4^{\circ}$ MSK (ZAMG, 2005a).

- Shallow-seated focal depths: according to both national (ZAMG, 2005b; Lenhardt et al., 2007) and foreign (USGS/NEIC, 2005) seismic records, the Fernpass region is affected by earthquakes with hypocentres located clearly above $6 \mathrm{~km}$. The most shallow-seated focal depths reach down to only approx. 3-4 km and, remarkably, cluster near the Tschirgant massif, which was affected by polyphase and deep-seated slope failures
(Fig. 7). According to the ZAMG data, some of these seismic events show low magnitudes $\mathrm{M}=1.2-1.8$, but nevertheless pronounced epicentral intensities $I_{0}=3.0$ $4.0^{\circ} \mathrm{MSK}$ due to their shallow-seated focal depths. Projected into a structural transect (Eisbacher et al., 1990), these earthquakes indicate active tectonics in the thrust sheets of the Northern Calcareous Alps near the base thrust of the Inntal nappe.

\section{Synopsis of data compilation}

Dating data of about 60 rock slope failures and about 60 debris flows in the Tyrol and its surroundings have been compiled in a geodatabase and visualised in maps and graphs (Table A1, Figs. 8, 9, 10). As a first result, these data show a rather continuous temporal distribution of events in the Holocene, without longer time gaps. However, there is no evidence for increased landslide activities due to deglaciation processes during the Late-Glacial and early Holocene. In Austria, late-glacial ages have only been established for a few rock slope failures, e.g. the large Almtal rockslide (Upper Austria; Van Husen et al., 2007a) and a failure event at the Pletzachkogel (Tyrol; Patzelt, 2004b). The accumulation of major debris flows in the Tyrolean Inn valley dates back to at least $13400 \pm 600{ }^{14} \mathrm{C}$ yrs BP (Weber, 2003).

As a second result, slope collapses in the early PostGlacial, at about 10500-9400 cal BP, are only indicated by a few dates, but they comprise some of the largest failure events in the Alps. Among these are the deep-seated rockslides at Flims (volume at least 8000 million $\mathrm{m}^{3}$; Poschinger et al., 2006) and Kandertal (approx. 800 million $\mathrm{m}^{3}$; Tinner et al., 2005) in Switzerland as well as at Köfels (approx. 3200 million $\mathrm{m}^{3}$; Brückl et al., 2001) and Hochmais (approx. 30 million $\mathrm{m}^{3}$; Zangerl et al., 2007) in the Tyrol (Austria). Before and after these events, the compiled data show a lower frequency of dated landslides. Subsequent to $7500 \mathrm{cal}$ BP, several smaller events, but also the huge Wildalpen rockslide (Styria, Austria; volume approx. 1400 million $\mathrm{m}^{3}$; Van Husen and Fritsch, 2007b) took place.

As a third result, numerous landslides were found to cumulate in the middle Holocene, with a significant emphasis in the Subboreal at about 4200-3000 cal BP (Prager et al., 2007). This temporal cluster, in graphs indicated by a less steep trend line of dated events (Figs. 9, 10), comprises some of the largest rockslides in the Tyrol. Among these are the deep-seated events at the Fernpass, Eibsee, Tschirgant and Tumpen, which also cluster spatially ("Fernpass cluster"), as well as those at the Hintersee and Pletzachkogel (Figs. 1, 8).

Periods of increased slope deformations in the early and middle Holocene were also established in adjacent regions of Austria (Figs. 8, 10). In central Switzerland two clusters of raised landslide activity were observed at about 10 000-9000 and 5200-1500 cal BP (Raetzo-Brülhart, 1997). In eastern 


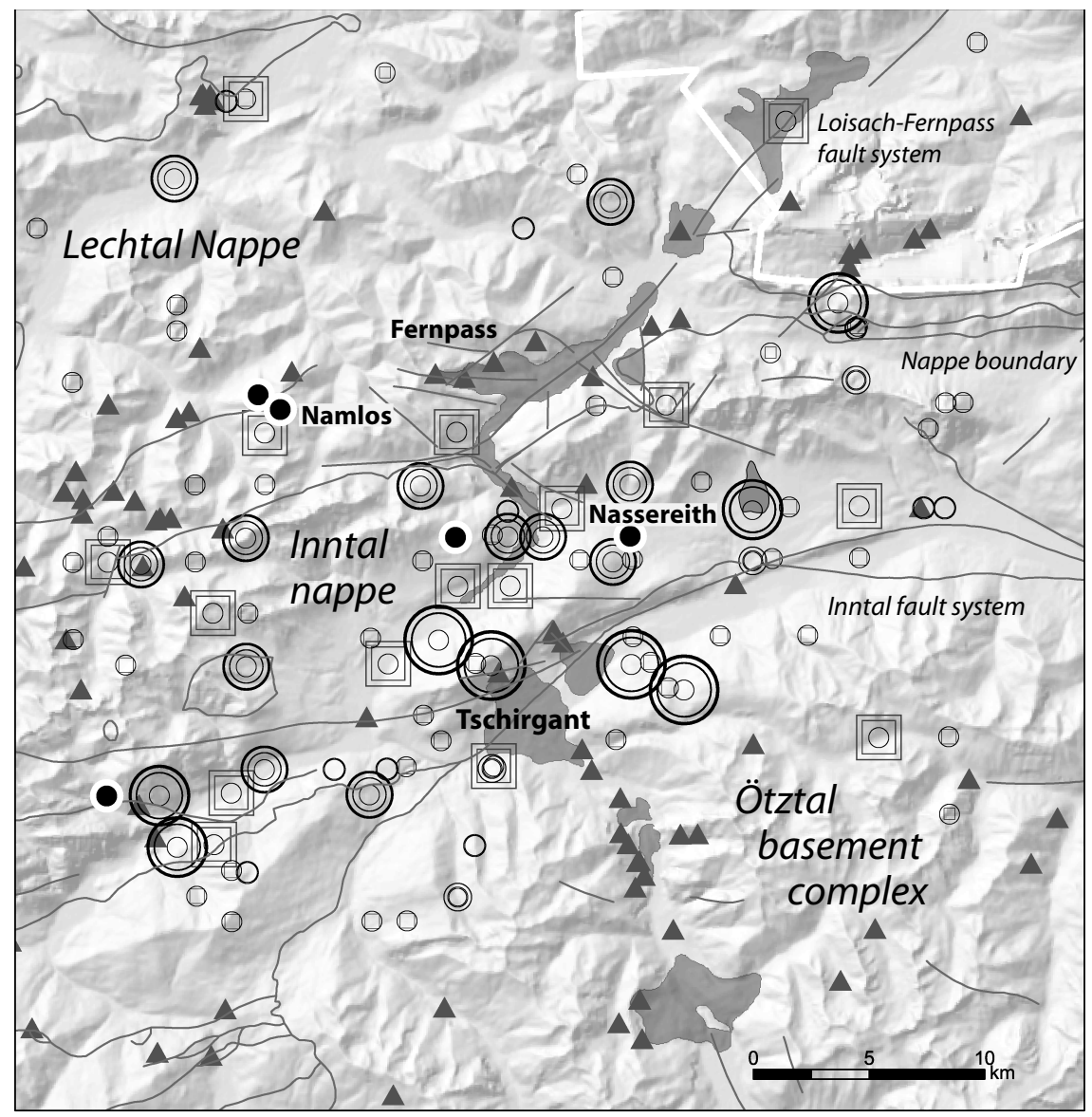

- Mass movements (late-glacial to recent)

Large Rockslides

Faults

Focal depth $[\mathrm{km}]$

ZAMG

(1951 - 2005)

USGS/NEIC

(C) 3<smiles>[c]1ccccc1</smiles>

(1) 5

(C) 6

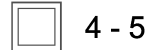

$7-12$

$\square$ 7- 11

$\square \quad 15-48$

lo $=6.5-7.5$

(1886 - 1958)

Fig. 7. Earthquake epicentres and landslides in the Fernpass region (cf. Fig. 1). Data courtesy of ZAMG (2005b) and downloaded from USGS/NEIC (2005) (Remark: some locations of coeval earthquakes may differ between these databases and thus may mistakenly suggest an increased earthquake activity when plotted together in maps).

Table 1. Basic parameters of strong earthquakes in the Fernpass region, Tyrol (Drimmel, 1980).

\begin{tabular}{lllllll}
\hline Date & Long. & Lat. & Depth & $\mathrm{M}^{(2)}$ & $I_{O}^{(3)}$ & Epicentre \\
\hline $1886-11-28$ & 10.8 & 47.3 & $8-12 \mathrm{~km}$ & 5.2 & 7.5 & Nassereith \\
$1910-07-13$ & 10.9 & 47.3 & $8-12 \mathrm{~km}$ & 4.8 & 7 & Nassereith-Silz \\
$1930-10-08$ & 10.7 & 47.35 & $8-12 \mathrm{~km}$ & 5.3 & 7.5 & Namlos \\
$1933-11-08$ & 10.7 & 47.35 & $8-12 \mathrm{~km}$ & 4.6 & 6.5 & Namlos \\
$1958-09-30$ & 10.6 & 47.2 & $8-12 \mathrm{~km}$ & 4.5 & 6.5 & Lechtal Alps near Landeck \\
\hline
\end{tabular}

(1) Longitude, Latitude: Decimal Geographic Coordinates (Date ED50), ${ }^{(2)}$ Magnitude M, ${ }^{(3)}$ epicentral intensity $I_{O}$ (based on the 12-point macroseismic scale by Medvedev-Sponheuer-Kárnìk MSK).

Switzerland, five temporal pulses of slope instabilities were detected between 11500-10 250, 6250-4800, 3500-2100, 1700-1150 and 750-300 cal BP (Dapples et al., 2003). In the Italian Dolomites two striking age-clusters were identified, one early Post-Glacial at about $13000-9000$ cal BP and the other one in the Subboreal at about $6500-2300 \mathrm{cal}$ BP (Soldati et al., 2004). In the Trentino (Italy), different phases of rock slope failures have been determined at about
6500, 4700, 2200 and $1000 \mathrm{cal}$ BP (Bassetti and Borsato, 2007). Data from outer-Alpine regions in Europe have not been compiled in this study, but they also point to a temporal clustering of slope instabilities e.g. in the early and middle Holocene (e.g. Matthews et al., 1997; Bertolini, 2007).

As a fourth result, dated debris flows, ranging from smaller local events to larger alluvial fans in the main valleys, also indicate periods of fluctuating accumulation activity (Fig. 9). 


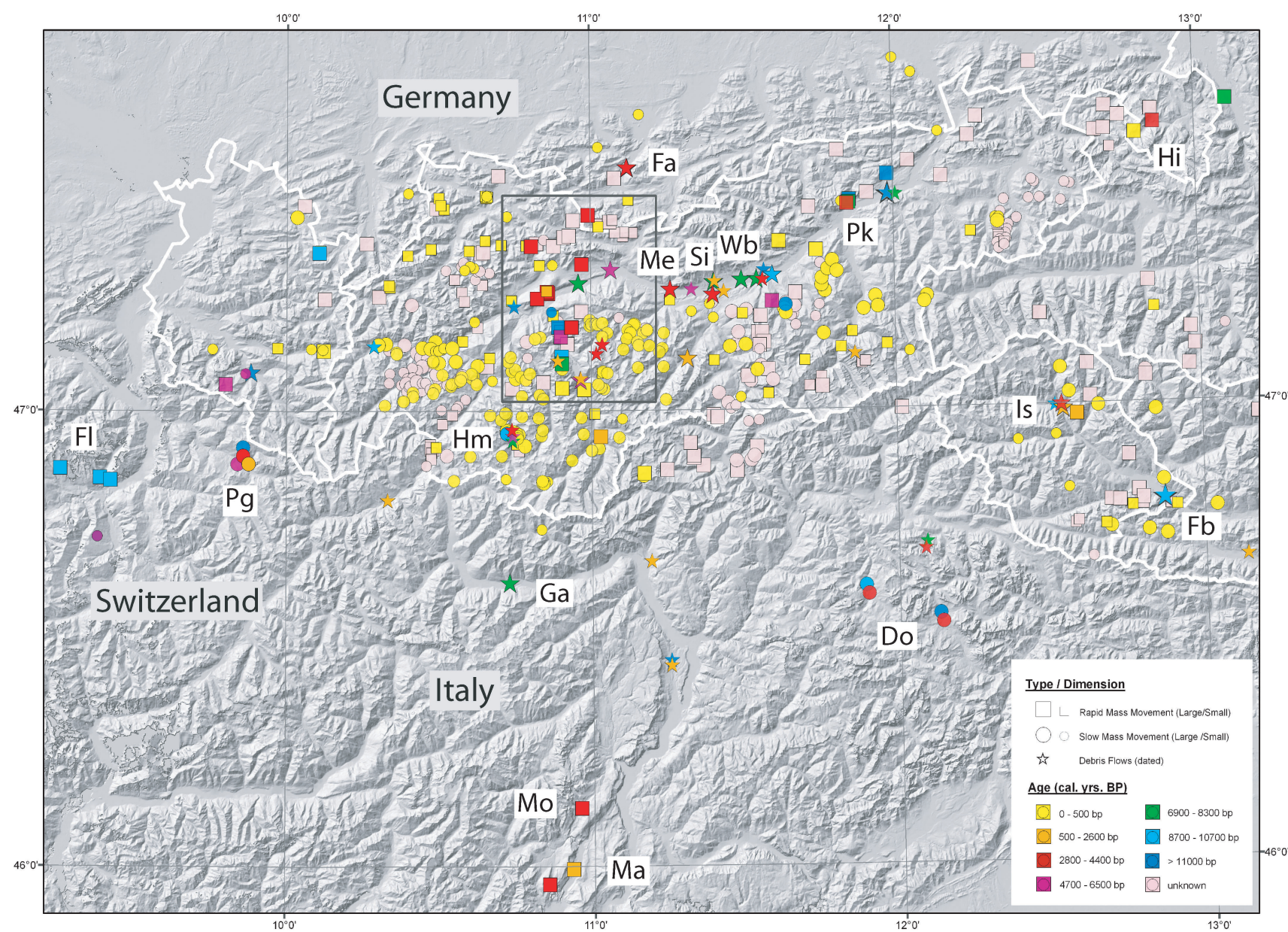

Fig. 8. Spatial and temporal distribution of mass movements in the Tyrol (Austria) and its surrounding areas. Beyond Tyrol only dated fossil landslides are shown. Temporally and spatially clustered landslides in the Fernpass region indicated by black rectangle (centre of the figure, cf. Fig. 1). Do: Dolomites rock slope failures, Fa: Farchant debris flow, Fb: Frauenbach debris flows, Fl: Flims rockslide, Ga: Gadria river, Hi: Hintersee rockslide, Hm: Hochmais rockslide, Is: Isel river, Ma: Marocche di Dro, Mo: Molveno rockslide, Me: Melach river, Pg: Prättigau rock slope failures, Pk: Pletzachkogel rockslides, Si: Sill river, Wb: Weißenbach river.

With respect to the Tyrolean Inn valley and its tributary rivers, Patzelt (1987) established phases of raised accumulation, firstly at about $9400{ }^{14} \mathrm{C}$ yrs BP (approx. $10630 \mathrm{cal}$ BP), secondly between 7500-6000 (approx. 8350-6840 cal BP) and thirdly at about $3500{ }^{14} \mathrm{C}$ yrs BP (approx. $3780 \mathrm{cal}$ BP). According to this, some of the largest alluvial fans in Northern and Southern Tyrol, e.g. those of the rivers Gadria and Weißenbach, show significantly increased activity at about 7900-7100 cal BP. Other major debris flows accumulated considerably in the Subboreal, e.g. the rivers Sill and Melach at about 3700-3600 cal BP. In between these periods, at about $6000-4500{ }^{14} \mathrm{C}$ yrs BP (approx. 6840-5170 cal BP) the Inn valley was affected by a distinctive phase of fluvial erosion (Patzelt, 1987).

In the Lower Inn valley, two major phases of increased fluvial debris accumulation have recently been determined (Weber, 2003): within the first phase, the main rivers Inn and Wildschönauer Ache show significantly increased accumulation between approx. $17000-14000 \mathrm{cal} \mathrm{BP}$ and mainly between approx. 7600-6000 cal BP; after a period of fluvial erosion, a second phase of increased debris accumulation occurred between approx. 4500(?) cal BP and the 19th century. Some minor debris flows in this region are characterised by fluctuating activity between approx. 12500 and $2050 \mathrm{cal}$ BP (Weber, 2003; Table A1).

Increased fluvial dynamics and debris accumulations in the middle to younger Holocene have also been established at other sites in the Tyrol and have recently been incorporated into a geodatabase (Figs. 8, 9). These records comprise the large Farchant debris flow (Fernpass region, dated 4340 and $3180 \mathrm{cal} \mathrm{BP}$ ), the main river Isel (dated 5700 $2600 \mathrm{cal}$ BP) and local events at Gepatsch/Kaunertal (dated 3990 cal BP), as well as data about sedimentological changes from fine to coarse deposits. The latter indicate phases of 


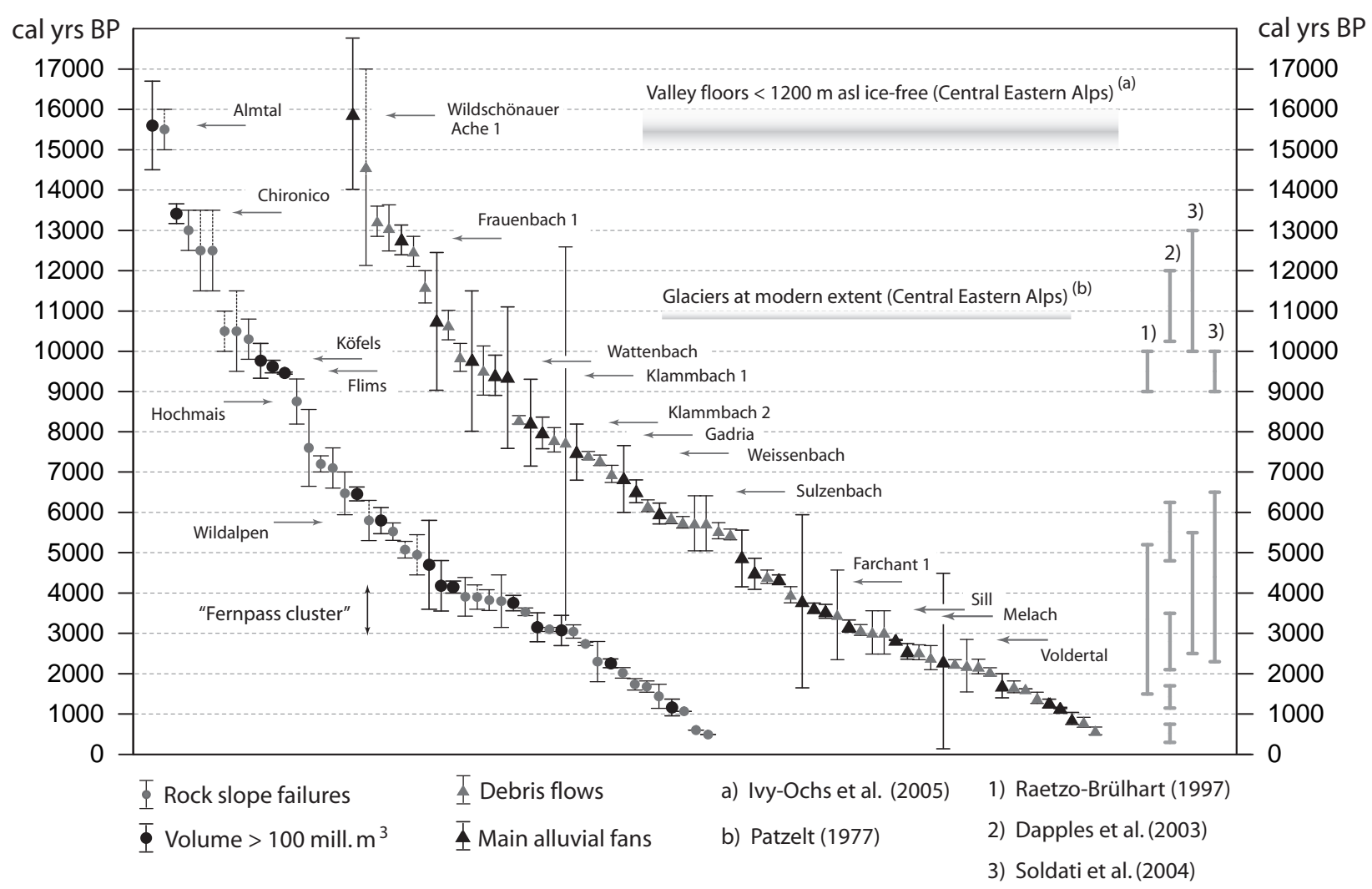

Fig. 9. Temporal distribution of fossil landslides in the Tyrol (Austria) and its surrounding areas (vertical axes: calibrated years BP, horizontal axes: dimensionless sequence of dated events; database: Table A1).

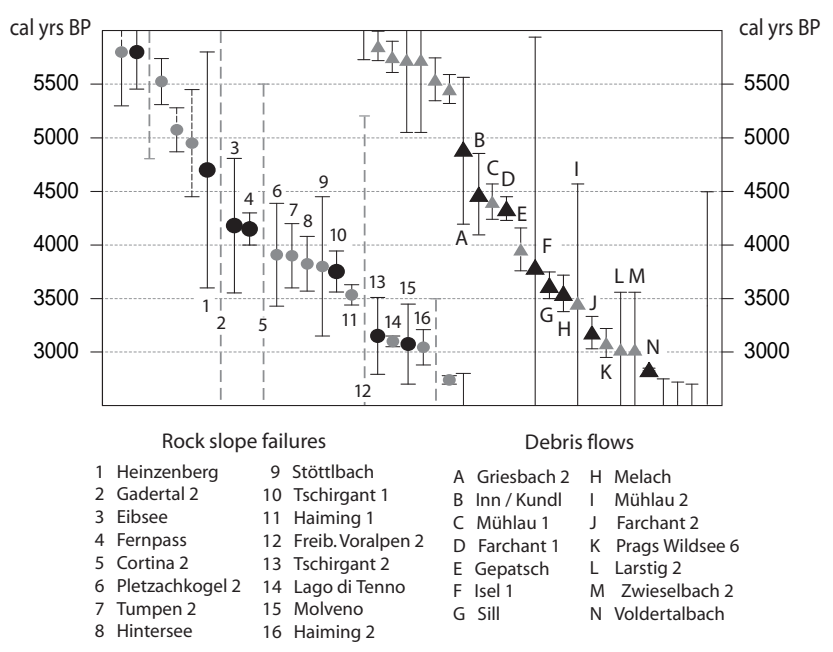

Fig. 10. Temporal distribution of middle Holocene landslides in the Tyrol and its surrounding areas (zoom-in of Fig. 9, modified).

increased fluvial dynamics, which were observed e.g. in the northern Ötz valley at the Längenfeld basin (starting at approx. $3400{ }^{14} \mathrm{C}$ yrs BP, i.e. approx. $3650 \mathrm{cal} \mathrm{BP}$ ), in the Stubai valley (prior to $1275 \mathrm{cal}$. BP; Blättler et al., 1995) and at some nearby torrents in the period between 3560-2590 cal BP (Mignon, 1971; Patzelt, 1987, 1999; Geitner, 1999; Veit, 2002; Table A1).

As a fifth result, some radiometric data, which are not spatially attributable when depicted in graphs (Figs. 9, 10), prove polyphase reactivations of predisposed vulnerabilities and multiphase slope failures in different geological settings, e.g. at:

- Fernpass (Fig. 2): a main event dating into the Subboreal, associated with a secondary rockslide and an unstable slope (Prager et al., 2006a, b),

- Tschirgant, Haiming (Fig. 3) and Pletzachkogel (Fig. 6): multiple, but clearly differentiable rockslide events, with intense slope activities in the Subboreal (Patzelt, 2004a, b),

- Tumpen (Fig. 4): several failure events, at least two of them being roughly dated, occurring within a relative small area (Poscher and Patzelt, 2000),

- Köfels (Fig. 5): one well established main event (Heuberger, 1966), succeeded by a secondary rockslide (Ivy-Ochs et al., 1998; Hermanns et al., 2006), 
- Several presently active landslides: pre-historical and/or historical precursory events documented at several active creeping slopes, e.g. at Gepatsch-Hochmais (Austria; Schmidegg, 1966), Heinzenberg (Switzerland; Weidner, 2000), La Clapière (France; Bigot-Cormier et al., 2005) and some catastrophic events, e.g. at Vajont (Italy; e.g. Hendron and Patton, 1987; Kilburn and Petley, 2003), Val Pola (Italy; e.g. Costa, 1991; Azzoni et al., 1992) and Randa (Switzerland; e.g. Sartori et al., 2003; Eberhardt et al., 2004).

\section{Discussion}

Deep-seated gravitational slope deformation is controlled by lithological, structural and morphological predisposition, by different time-depended long-term rock strength degrading processes and by shorter termed variable triggering factors. Detailed field studies of fossil and active landslides in the Tyrol indicate that these failures can basically be attributed to the complex intersection and coalescence of bedding and schistosity planes and brittle fault and joint systems, resulting in a substantial rock strength reduction extending to considerable depths (Brückl et al., 2004; Prager et al., 2006b, 2006c; Zangerl et al., 2007, 2008). Several of these deepseated gravitational slope deformations are encountered in seismically active regions and coincide temporally with periods of increased debris flow accumulations in the nearby main valleys. In view of these findings, rock strength degrading processes and parameters, which control slope instabilities in the Holocene, will subsequently be discussed.

\subsection{Glacial loading and unloading}

In the Eastern Alps, the stabilities of polyphasically and heteroaxially fractured rock units were fundamentally influenced by morphological changes in the Quaternary. In particular, repeated glacier advances and isostatic rebounds in the Pleistocene caused local stress perturbations (e.g. Grollimund and Zoback, 2000, Cossart et al., 2008) and thus reactivations of pre-existing discontinuities as well as initiations of loading fractures in the bedrock units. Subsequently, fluvio-glacial erosion, valley-deepening and postglacial decompression (cf. Ballantyne, 2002) uncovered favourably oriented sliding planes and caused substantial stress redistributions in the undercut and oversteepened slopes. Therefore, the high and unbalanced relief since the early Post-Glacial is certainly a main factor contributing to Alpine mass movements. Consequently, a few slopes, which were characterised by critical fracture densities and thus close to their stability limit equilibrium, failed after the late-Würmian ice retreat.

The late-glacial Gschnitz valley glaciers advanced, at the type locality in the central Eastern Alps, down to altitudes of about $1200 \mathrm{~m}$ asl not later than $15400 \pm 1400 \mathrm{yrs}$ ago (IvyOchs et al., 2005). This indicates that the toes of several unstable slopes, especially when east- and/or southward exposed as at Köfels, Fernpass and Tschirgant, bordered on thin dead-ice or even ice-free valley-floors and were not glacially buttressed at least since the Younger Dryas. Subsequently, late-Pleistocene glaciers suffered a rapid further meltdown until at about $9500{ }^{14} \mathrm{C}$ yrs BP (i.e. approx. $10850 \mathrm{cal} \mathrm{BP}$ ) they reached for the first time modern extents (Patzelt, 1972, 1977). Reforestation of valley slopes in the central Stubai and presumably also in the Ötztal Alps (both Tyrol, Austria) at elevations of approx. $2100 \mathrm{~m}$ a.s.l. was already in full swing at about $9600{ }^{14} \mathrm{C}$ yrs BP (Weirich and Bortenschlager, 1980; Bortenschlager, 1984), i.e. approx. $10950 \mathrm{cal} \mathrm{BP.}$

Concerning these data, even the early post-glacial landslides, among them some of the largest Alpine events e.g. Köfels, Kandertal, Flims and Hochmais did not fail immediately after glacier retreat and unloading, but occurred several 1000 years later (Fig. 9). This delay indicates that time-dependent rock strength degradation is controlled by basic parameters such as lithological, structural and morphological dispositions, and by variable processes such as dynamic loading and pore-pressure fluctuations. In combination, these factors promote progressive fracturing and can thus both prepare and trigger slope instabilities (Fig. 13).

\subsection{Subcritical fracture propagation}

Compiled landslide-dating shows a rather continuous temporal distribution in the Holocene and thus yields evidence that glacial decompression is not the only trigger. If this were the case, the majority of deep-seated slope failures would cluster immediately after late-glacial deglaciation, but this is not the case. This indicates a gradual reduction in slope stability after the glacier's retreat, continuously, by progressive failure, i.e. a long-term process resulting from stress redistributions at the oversteepened valley flanks. As a result, the general rock strength is intensively affected by fracture propagation and by a stepwise coalescence of pre-existing brittle discontinuities (e.g. Eberhardt et al., 2004), which both strongly depend on the existing stress field as well as on the fracture geometry and the joint network. Field investigations and subcrop data in the polymetamorphic rock units of the Gotthard massif (Switzerland) furthermore show that the joint densities increase significantly from deeper lying to higher lying bedrock units, and they also indicate a progressive occurrence of unloading fractures which are mainly oriented parallel to the slope (Zangerl, 2003). The coalescence of such discontinuities may initiate both the internal disintegration of rock masses and the development of potential sliding planes due to local stress concentrations.

Concerning the long-term behaviour of fractured rock masses, there are complex physical-chemical processes in fractures that enable slow crack propagation even below a critical stress-intensity factor threshold $\left(K_{I C}\right.$, Fig. 11). According to the model of sub-critical crack growth (Atkinson, 1984, 1987), crack propagation may be caused by different 
parameters (e.g. interactions of pore water pressure, stress corrosion, dissolution, diffusion, ion exchange and microplasticity). The processes involved, e.g. the weakening of crystal bonds through chemical pore-fluid activities in the crack tip, start when driving forces exceed a threshold $K_{0}$ (e.g. stress corrosion limit). At the critical level $K_{I C}$ (fracture toughness), cracks propagate dynamically and accelerate up to a velocity close to the speed of sound in the rocks. The application of this fracture mechanical model to unstable slopes would mean that fracture density and persistence continuously increase over a longer period of time. This in turn would lead to a continuous decrease in slope stability and result in a slope failure, when a strength threshold is reached. The generally complex processes of sub-critical crack growth depend on the interaction of several parameters, e.g. in-situ stresses, bedrock mineralogy, fracture geometries and pore water characteristics. Being significantly favoured by high pore water pressures, lower bounds of fracture propagation velocities vary between a few centimetres and several decimetres per 1000 years (Fig. 11; Atkinson, 1984; Atkinson and Meredith, 1987).

\subsection{Dynamic loading}

Historically documented case studies indicate that landslides are predominantly triggered by heavy precipitation or by earthquakes, with large rock avalanches mostly being released by seismic events with magnitudes $M \geq 6$ (Eisbacher and Clague, 1984). According to Grünthal et al. (1998), earthquakes with EMS-98 epicentral intensities $I_{0} \geq 5$ can release smaller and relatively shallow-seated slope failures such as earthslides and minor rockfalls, whereas larger, deepseated rock slope failures such as landslides and massive major rockfalls require intensities $I_{0} \geq 7$ as a trigger.

General evidence of (paleo-)seismically triggered slope failures may be given by the coincidence of neotectonically active fault systems and age-clustered landslide distribution (Keefer, 1984; Jibson, 1996). Based on the spatial and temporal correlation of active faults, lacustrine mass flow deposits, subaerial rockfall deposits and speloethems, several major paleo-earthquakes in central Switzerland were recorded. These earthquakes, which occurred during the last $15000 \mathrm{yrs}$ in the late Pleistocene and Holocene and clearly affected larger regions, were characterised by magnitudes M>6.5-7.0 (Becker et al., 2005; Strasser et al., 2006). Corresponding studies yielded evidence that paleo-earthquake frequency in central Switzerland was increased in the late Pleisctocene - early Holocene, due to isostatic rebound after glacier retreat, and also in the last $4000 \mathrm{yrs}$, due to seismic activations of brittle fault systems (Monecke et al., 2006).

This may also be the case in the Fernpass region, where several fossil landslides cluster spatially and temporally and are also situated closely to seismically active master faults, e.g. the NE-trending brittle Inntal fault system (Fig. 7). These systems caused deep-seated rock fragmentation and

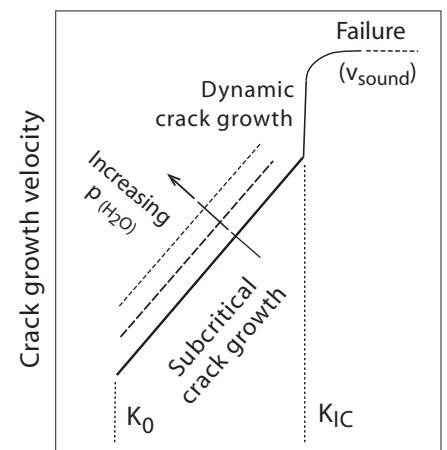

Stress intensity $\left(\mathrm{K}_{\mathrm{l}}\right)$

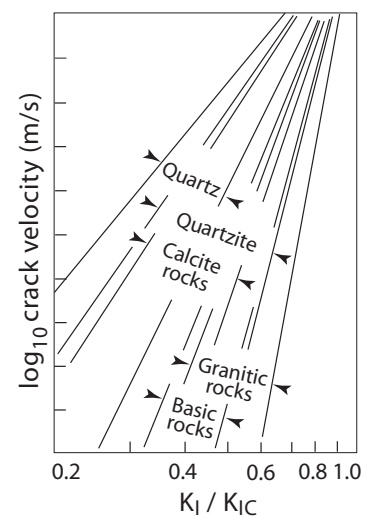

Fig. 11. Schematic illustrations showing (on the left) crack growth velocity versus stress intensity factor $\left(\mathrm{K}_{I}\right)$ : subcritical crack growth starts when driving forces exceed a threshold $\mathrm{K}_{0}$. Approaching to a critical level $\mathrm{K}_{I C}$, cracks propagate dynamically to near the velocity of sound in the rocks. Note that increasing pore pressures $\mathrm{p}\left(\mathrm{H}_{2} \mathrm{O}\right)$ may significantly accelerate crack propagation velocities. On the right, variations of subcritical tensile crack growth in different rock types are shown $(\log / \log$ plot; arrows indicate range of experimentally obtained data; modified after Atkinson, 1984, 1987).

enabled fluvio-glacial valley deepening in the vicinity of several failed slopes, e.g. at Fernpass, Eibsee, Ehrwald, Tschirgant and Pletzachkogel. Regional seismic data show that earthquakes close to the Fernpass feature epicentral intensities $I_{0} \leq 7.5^{\circ}$ and rank among the strongest ever measured in Austria (Drimmel, 1980). The fact that some of these earthquakes triggered rockfalls and changed the hydraulic flow field locally (Schorn, 1911, 1922, Klebelsberg, 1930) suggests that the release of fossil rockslides of similar ages could have been essentially favoured by seismic shaking. Concerning the Tyrol, maximum earthquake magnitudes $M_{\max }=6.1$ $(+0.4)$ for the Inn valley and $5.6(+0.4)$ for the West Tyrol (incl. Fernpass region) have been modelled (Lenhardt et al., 2007). Considering the ranges of the calibrated ${ }^{14} \mathrm{C}$-dating (Fig. 10, Table A1), some of the spatially clustered rockslides in the Eibsee, Fernpass, Tschirgant, Stöttlbach and Tumpen region may be of the same age and may thus simultaneously have been triggered by earthquakes. But with the exception of the prominent Dobratsch rockslide 1348 $\mathrm{AD}$ in Carinthia/Austria (Eisbacher and Clague, 1984), a few (paleo-)seismic records from Switzerland (Becker et al., 2005) and some events triggered by the 1998-earthquake in NW-Slovenia (Vidrih et al., 2001), seismically induced slope failures documented in Central Europe tend to be of minor dimensions.

Yet, active fault systems can not only trigger mass movements, but can produce intensely fractured rock masses extending to substantial depths, including potential sliding planes. Some regions in the Tyrol are characterised by high ground accelerations of up to $1 \mathrm{~m} / \mathrm{s}^{2}$ (ÖNÖRM B4015, 2007), others are affected by less energetic, but 
shallow-seated earthquakes with foci at depths of only 3$4 \mathrm{~km}$ (Fig. 7). These earthquake intensities are below any threshold likely to trigger deeper-seated landslides, but even subcritical dynamic loading may accelerate progressive fracture propagation within the affected rock units. Comparable load tests show that samples with discontinuities are not subject to any further fracture propagation under static loading conditions below their critical failure load. Contrary to this, dynamic loading initiates fracture propagation at values far below the critical load (Gross, 1996). Such a fatigue crack growth, resulting from the interaction of tension and pressure stresses (Chernyshev and Dearman, 1991), can step by step weaken intact rock bridges and raise the effective joint porosity. Applying these findings to unstable slopes gives evidence that repeated seismic shaking can encourage landslides by reducing rock strengths and changing hydraulic conductivities.

\subsection{Fault healing and fracture cementation}

Fault models indicate that during interseismic periods processes of fault healing and sealing, i.e. rock strength recovery due to compaction and cementation of fractures related to active faults, occur. Thus, in calcitic environments, at depths between 2 and $5 \mathrm{~km}$, micro-fracture porosities may be closed in about 1000 yrs (Renard et al., 2000). With respect to subaerially exposed rock units this implies that meteoric cementation of brittle discontinuities may continuously increase slope stability (Fig. 13).

But the well exposed scarp areas of the Eibsee and Tschirgant carbonate rockslides, and especially the deeply incised niche at the Fernpass show intense deformation along brittle fault and fracture zones with kakirites and uncemented, thus open, discontinuities extending to substantial depths. Meteoric cementation, in general terms of efficiency and extent, strongly depends on the climate, i.e. humidity and circulating pore-water, as well as on bedrock mineralogy. In most meteoric diagenetic environments, calcium carbonate is the most wide-spread type of cement (Tucker and Wright, 1990). Field observations revealed that in limestone terrains, probably due to the availability of nucleation sites, veins and joints filled by calcium carbonate cements are widespread. Contrary to this, in dolomite and crystalline bedrock units, open fractures devoid of cement are frequently encountered. Thus, the thick dolomitic successions of the Wetterstein and Hauptdolomit Formation, which form the Fernpass and Tschirgant scarp, exhibit less active cementation processes. This, in turn, favours the coalescence of brittle discontinuities and provides potential sliding planes.

As far as fracture healing is concerned, the scarp areas of the Eibsee and Ehrwald rockslides (see Sects. 4.1, 4.2) appear to represent special cases. Situated at north- and west-exposed cliffs of the Zugspitze massif (2961 m a.s.l.) and reaching elevations of up to $2600-2800 \mathrm{~m}$ a.s.1., vadose cementation processes of Wetterstein Formation limestones seem to have been retarded by the occurrence of permafrost and were consequently less effective. Recent permafrost conditions, at least in the upper third of the Zugspitze massif, are indicated by metre-sized ice-filled clefts and joints (Knauer, 1933; Körner and Ulrich, 1965; Gude and Barsch, 2005).

\subsection{Climate changes}

Central Greenland ice cores and Lake Ammersee (Bavaria, Germany) isotope records show rapid climate shifts between 15 and $5 \mathrm{ky}$, with significant warming at about $14.5 \mathrm{ky}$ (transition Oldest Dryas-Bølling) and $11.5 \mathrm{ky}$ (transition Younger Dryas-Preboreal; Grafenstein et al., 1999). After the Younger Dryas cold period, glaciers in the Central Eastern Alps rapidly retreated to modern extents. Subsequently, several smaller but nevertheless significant glacierand forest-line fluctuations indicate considerable changes of the Holocene climate. Glaciers varied in size around modern extents, yet were smaller for longer periods in the middle and early Holocene (Patzelt, 1977, 2005). The Lake Ammersee records clearly show the cold incursion of the $8.2 \mathrm{ky}$ event and a plateau-like temperature trend with only minor fluctuations in the middle to younger Holocene (Grafenstein et al., 1998, 1999).

Glacier studies in the Central Eastern Alps show that long periods in the Holocene were characterised by favourable climatic conditions with average summer temperatures slightly higher than at present. These periods were repeatedly interrupted by relatively short, but pronounced deteriorations with multiple glacier advances, like the Löbben advance at about 3750-3250 cal BP (Patzelt and Bortenschlager, 1973; Fig. 12). In line with this, Austria's largest glaciers, the Pasterze and the Gepatschferner, were on several occasions and even for longer phases between 10450 and $3650 \mathrm{cal} \mathrm{BP}$ smaller than at present and experienced several minor fluctuations between $3650 \mathrm{cal} \mathrm{BP}$ and the waning Roman age, until they reached their modern dimensions (Nicolussi and Patzelt, 2000, 2001).

Also in the Central Swiss Alps, unstable Holocene climatic conditions are indicated by glacier fluctuations featuring at least eight phases of significant glacier recession with several cold-wet periods in between. In the middle Holocene, in the period between 5290-3870 and 3640-3360 cal BP, glaciers were smaller than at present due to moderate climatic conditions (Hormes et al., 2001). Except for the non-correlating, but significantly high lake levels at 3500$3100 \mathrm{cal}$ BP, younger Holocene lake level maxima in the Swiss Alps coincide with glacier advances. Thus these periods were characterised by a general drop in winter temperatures and an increase in summer moisture, controlled by fluctuations in solar activity (Holzhauser et al., 2005).

Compiled data of several sub-regions in Europe and of a few deep-seated landslides in the Alps suggest an increase in all types of rapid mass movements (i.e. landslides, debris flows, snow avalanches) in the middle and late Holocene, i.e. approx. after $5000 \mathrm{cal}$ BP. Since this positively 
correlates with major phases of solifluction and glacier advances, landslides may contain proxy data on longer term variations of paleo-precipitation (Berrisford and Matthews, 1997; Matthews et al, 1997).

In Switzerland, Raetzo-Brülhart (1997) attributes two distinct clusters of raised landslide activity, at about 10000 9000 and $5200-1500 \mathrm{cal} \mathrm{BP,} \mathrm{to} \mathrm{warmer} \mathrm{and/or} \mathrm{more} \mathrm{hu-}$ mid paleoclimatic conditions. Dapples et al. (2003) correlate five late-glacial to Holocene pulses of increased landslide dynamics with glacier advances, increased solifluction and sedimentary changes within lacustrine deposits (Fig. 12). Based on this, climatic deteriorations such as colder and especially more humid conditions controlled slope instabilities at about 11 500-10 250, 6250-4800, 3500-2100, 1700-1150 and $750-300 \mathrm{cal}$ BP. Major landslide activities in the latest Pleistocene were succeeded by fluctuating activities due to variable climatic conditions, until approx. around 38003400 cal BP a climatic shift towards colder and wetter conditions led to another significant rise in slope activities (Dapples et al., 2003; Raetzo and Lateltin, 2003). Regionally, this climatic influence may have been further intensified by anthropogenic influences on vegetation (e.g. by forest clearing), which were indicated by significantly increased landslide activities in the Western Swiss Alps from 3650 cal BP onwards (Dapples et al., 2002).

In the Italian Dolomites, Soldati et al. (2004) also differentiated between two striking age clusters of landslides: an early post-glacial one at about $13000-9000 \mathrm{cal} \mathrm{BP}$, which is due to deglaciation processes and was probably favoured by increased precipitation and/or permafrost meltdown, and a younger one, at about 6500-2300 cal BP in the Subboreal, which is again assumed to correlate with an increase in precipitation. In the Northern Apennines (Italy), the majority of dated landslides yielded ages younger than $5000 \mathrm{cal}$ BP and were assumed to correlate with climatic deteriorations (Bertolini, 2007; Bertolini et al., 2004).

However, several rockslides in higher Alpine environments occurred in periods of above-average temperature, when slope stabilities have been decreased by glacial debuttressing and/or thawing of permafrost (e.g. Geertsema, 2007). On according slopes, permafrost degradation may generally contribute to slope instabilities (Davies et al., 2001; Ballantyne, 2002; Gude and Barsch, 2005). Warming permafrost may be attributed to heat conduction and water percolation in fractures, i.e. crucial factors promoting failure in steep bedrock slopes (Gruber and Haberli, 2007). In view of these findings, thawing permafrost might have played a role during warmer periods in the Holocene, especially in the early Postglacial. Based on the radiometric dating of the Kandertal rockslide (Switzerland), Tinner et al. (2005) supposed that increased slope instabilities during the early Holocene were climatically controlled by a rise in precipitation and mainly by above-average (summer-)temperatures, which might have caused a withdrawal of permafrost due to a post-glacial climatic optimum. Temporally, the failures of

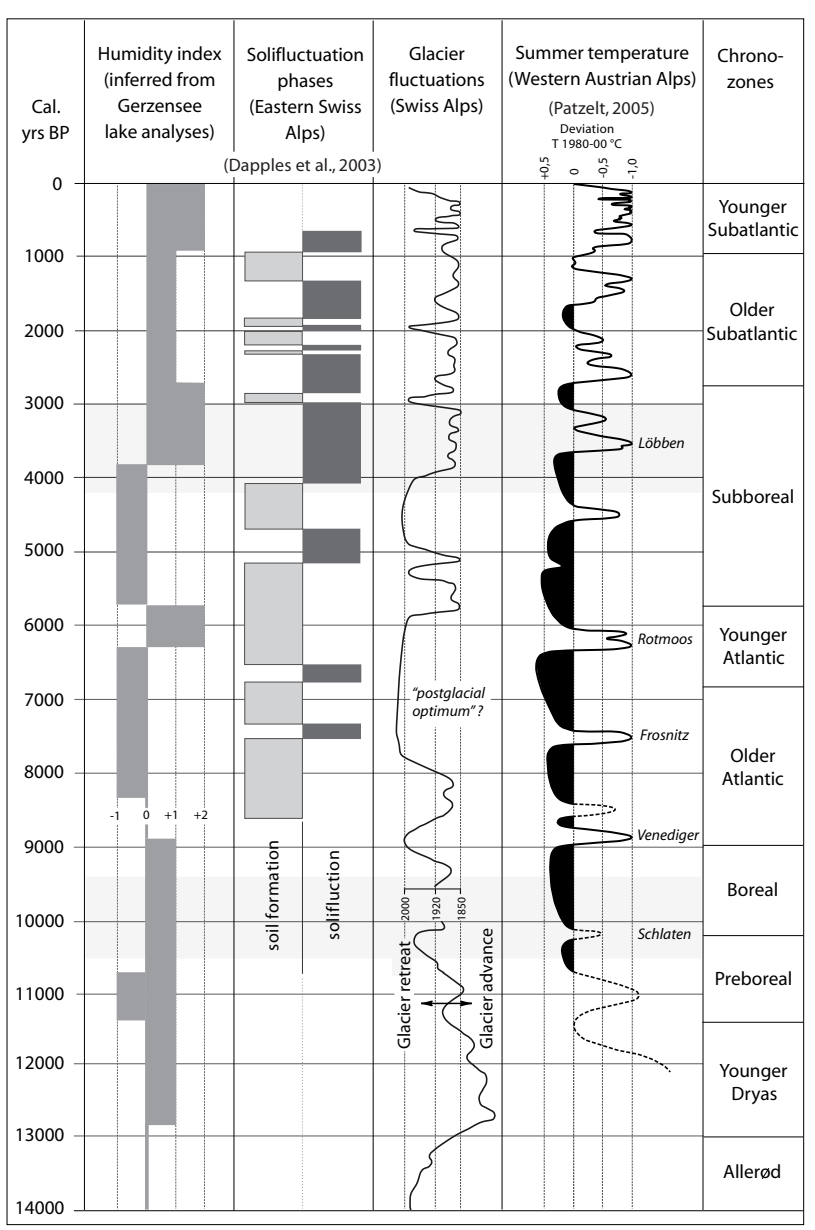

Fig. 12. Comparison of Late-glacial to Holocene paleoclimatic indicators of lake Gerzensee (-1: dry, 0: normal, +1 : wet, +2 : very wet), solifluctuation activity and glacier fluctuations (Dapples et al., 2003) with combined glacier- and forest-line data featuring some significant glacier advances in the Austrian Central Alps (Patzelt, 2005).

some deep-seated rockslides in the early Holocene (e.g. at Köfels, Kandertal, Flims and Hochmais) coincide with an early phase of increased, precipitation-controlled, raised debris flow activities in the Tyrolean Inn valley, occurring at about $9400{ }^{14} \mathrm{C}$ yrs BP (Patzelt, 1987), i.e. approx. $10630 \mathrm{cal}$ BP.

Compiled dating data also indicate a significantly heightened landslide activity in the Subboreal at about 4200$3000 \mathrm{BP}$, which is clearly not directly linked to deglaciation processes. Several of these events, amongst them some of the largest rockslides in the Alps, are encountered in the Tyrol. They cluster both temporally and spatially ("Fernpass cluster"; Figs. 8, 10) and correlate with the activities of several large-scale debris flows in nearby major valleys. A phase of increased alluvial accumulation in the Inn valley, at about $3500{ }^{14} \mathrm{C}$ yrs BP (approx. $3780 \mathrm{cal} \mathrm{BP}$ ), was 


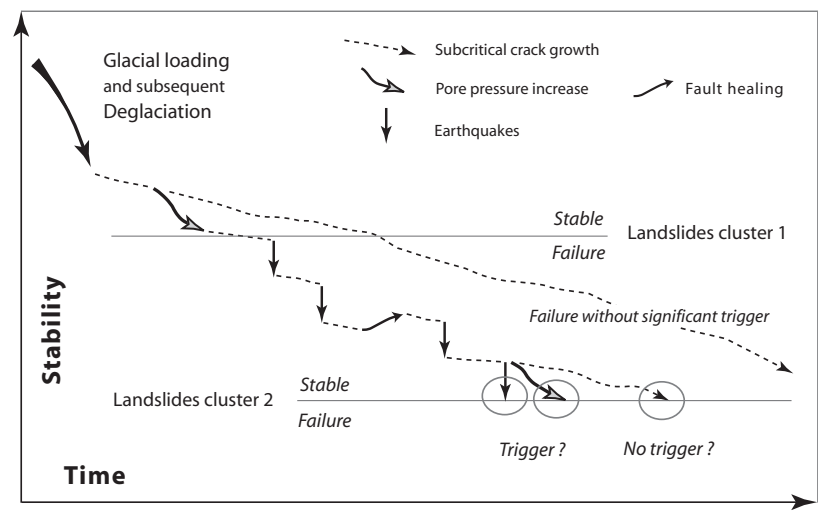

Fig. 13. Conceptual model for rock strength degrading processes in the Post-Glacial versus time (dimensionless).

established for some main tributaries such as the rivers Sill and Melach (Patzelt, 1987). This and the activities of local torrents and debris flows (Table A1) as well as glacier advances in the Austrian Central Alps (Fig. 12) indicate periods of greater water supply in the catchment areas.

Another coherent proxy for paleo-precipitation in the Eastern Alps has not been established yet. In the Mediterranean area, speleothem isotope records from central Italy coincide with a time of significant sapropel deposition and suggest enhanced regional rainfall between ca 8.9 and $7.3 \mathrm{ky}$, with a maximum between 7.9 and $7.4 \mathrm{ky}$ (Zanchetta et al., 2007).

However, historically documented case studies show that increased precipitation is generally the dominant landslide trigger (Eisbacher and Clague, 1984; Gruner, 2006). Higher pore pressures favour large slope movements by increasing seepage forces and lowering the effective stresses respectively (e.g. Bonzanigo et al., 2000). They also accelerate the velocity of subcritical crack growth (Atkinson and Meredith, 1987) and reduce the friction angle of weathered and watersaturated rock surfaces, which is generally lower than that of dry and unweathered ones (e.g. Barton and Choubey, 1977).

Recent field studies in the Central Swiss Alps suggest that natural variations in groundwater pressure directly control seasonal slope deformations. The collected geodetic monitoring results show significant valley closures in the springtime, which are characterised by horizontal deformations of about $10-16 \mathrm{~mm}$ and by vertical uplifts of about $10 \mathrm{~mm}$. These elastic, reversible deformations normal to the valley axes correlate positively with groundwater recharge rates (Löw et al., 2007). In the long run, such annual openings and closures of valleys may, comparable to dynamic loadings by subcritical earthquakes, promote material fatigue due to brittle fracture propagation and may thus favour progressive failure of predisposed slopes.

Structural field investigations and subsurface data obtained at the basal Tschirgant massif (Tyrol, Austria), which is characterised by polyphase rockslide events (Sects. 4.4, 4.5), also yielded evidence of coupled hydro-mechanical destabilising processes. Here a test drill, at the base of the Haiming scarp, penetrated approx. $670 \mathrm{~m}$ subhorizontally to the north and proved the existence of an effective water table. In the heavily fractured and thus highly permeable dolomites, dammed to the south by low permeable siliciclastics of the Raibl Group, steeply inclined hydraulic gradients and high pore pressures of up to 43 bar were measured (personal communication, Intergeo Consultants, Salzburg, Austria, 2005). These data suggest that here deep-seated slope deformations could have been favoured by climatically controlled groundwater level fluctuations.

\section{Conclusions}

In the Tyrolean Eastern Alps, several well-exposed scarp areas show that slope failures were clearly structurally controlled by fracture propagation and the coalescence of brittle fault and joint systems. Morphological changes, due to fluvio-glacial valley deepening in the Pleistocene, uncovered preferentially orientated sliding planes and caused substantial stress redistributions in the undercut slopes. Since then, complex and time-dependent processes of subcritical fracture propagation have affected slope stabilities.

In order to identify potential causes and triggers of landslides, a first comprehensive compilation of dated mass movements in the Tyrol and its surroundings has been made. It reveals that the majority of Holocene mass movements were evidently not directly triggered by deglaciation processes, but needed a preparation time of some 1000 years, after the ice withdrawal, until the slopes collapsed. Some of the largest landslides in the Alps occurred in the early Holocene, at about 10500-9400 cal BP. Remarkably, several deep-seated rockslides in the Tyrol were found to cluster temporally, at about 4200-3000 cal BP, and some of them also cluster spatially. This indicates striking environmental changes in this region in the middle Holocene.

In the Tyrol, several large rockslides are encountered near seismically active fault systems. Regional earthquake data record seismic events with comparatively high magnitudes $\mathrm{M} \leq 5.3$ and epicentral intensities $I_{0} \leq 7.5^{\circ}$ as well as others, which are characterised by lower intensities but feature shallow-seated hypocentres located at depths of only 3-4 $\mathrm{km}$. Active faults can not only directly trigger mass movements, but they can also produce intensely fractured and uncemented rock masses. Thus, repeated dynamic loading, even if at subcritical energy levels, initiates brittle fracture propagation and promotes slope instabilities.

Temporally, quite a few rock slope failures coincide with (i) dated landslides in the surrounding regions, (ii) increased debris flow activities and, partially, with (iii) glacier fluctuations in the Austrian Central Alps. In combination, these data may be proxy of paleoclimatic conditions and may indicate periods of raised precipitation and groundwater flows. 
This in turn, controls the pore pressure within fractured rock masses and favours progressive failure. Thus, structurally and morphologically predisposed mass movements were prepared and triggered not just by a single cause, but by the complex and polyphase interactions of several rock strength degrading processes. Deep-seated slope deformations may be attributed to critical fracture densities due to the propagation and coalescence of brittle discontinuities. This is favoured by different time-dependent and interacting processes which comprise (a) stress redistributions due to glacial loading and unloading, (b) subcritical crack growth, (c) seismic activity and (d) climatically controlled pore pressure changes. Any of these destabilising mechanisms, even if only at subcritical thresholds, can trigger a failure event if slope stability is already close to its limit equilibrium.

\section{Appendix}

Fossil mass movements in the Tyrol (Austria) and its surrounding areas: chronology of dated events, listed from old to young 


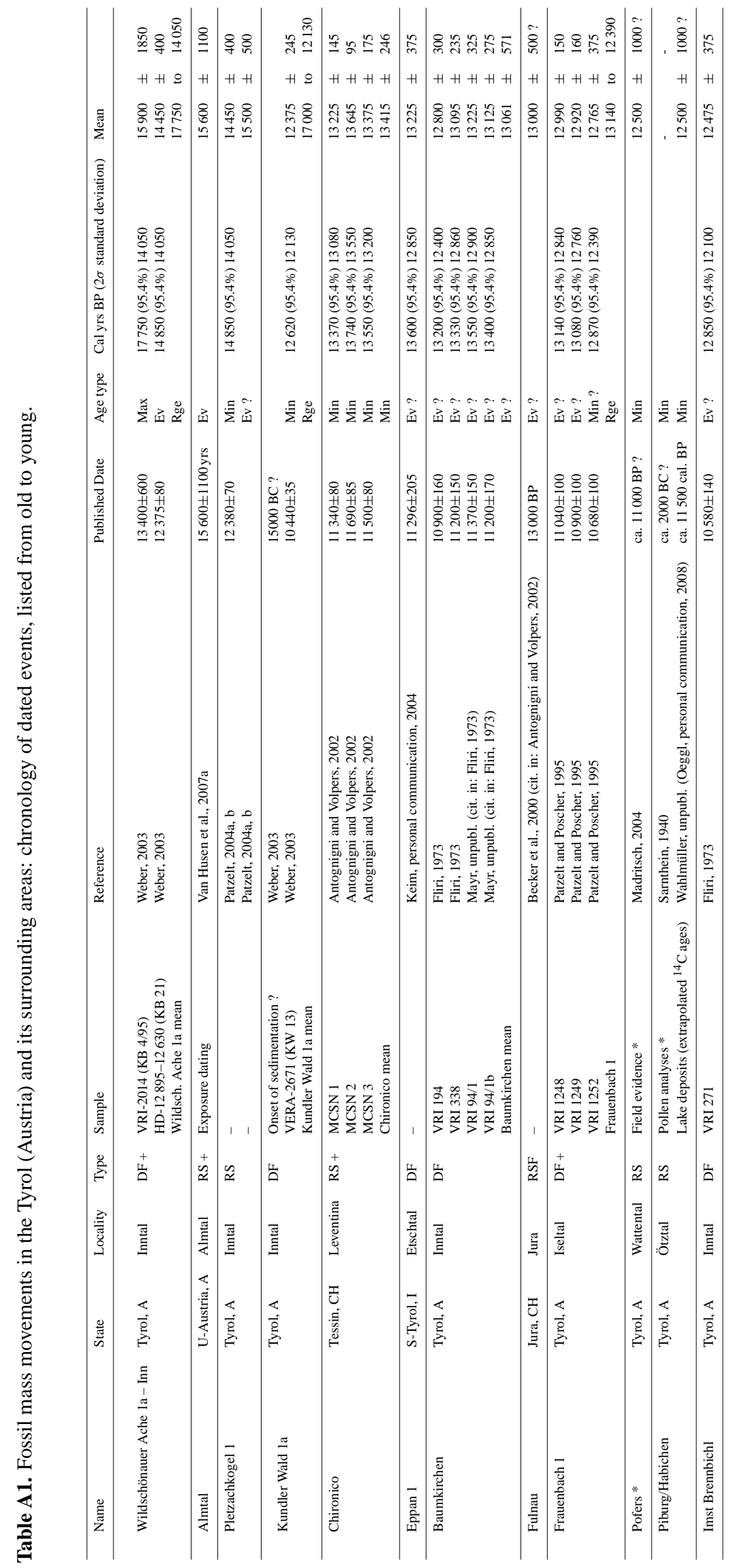




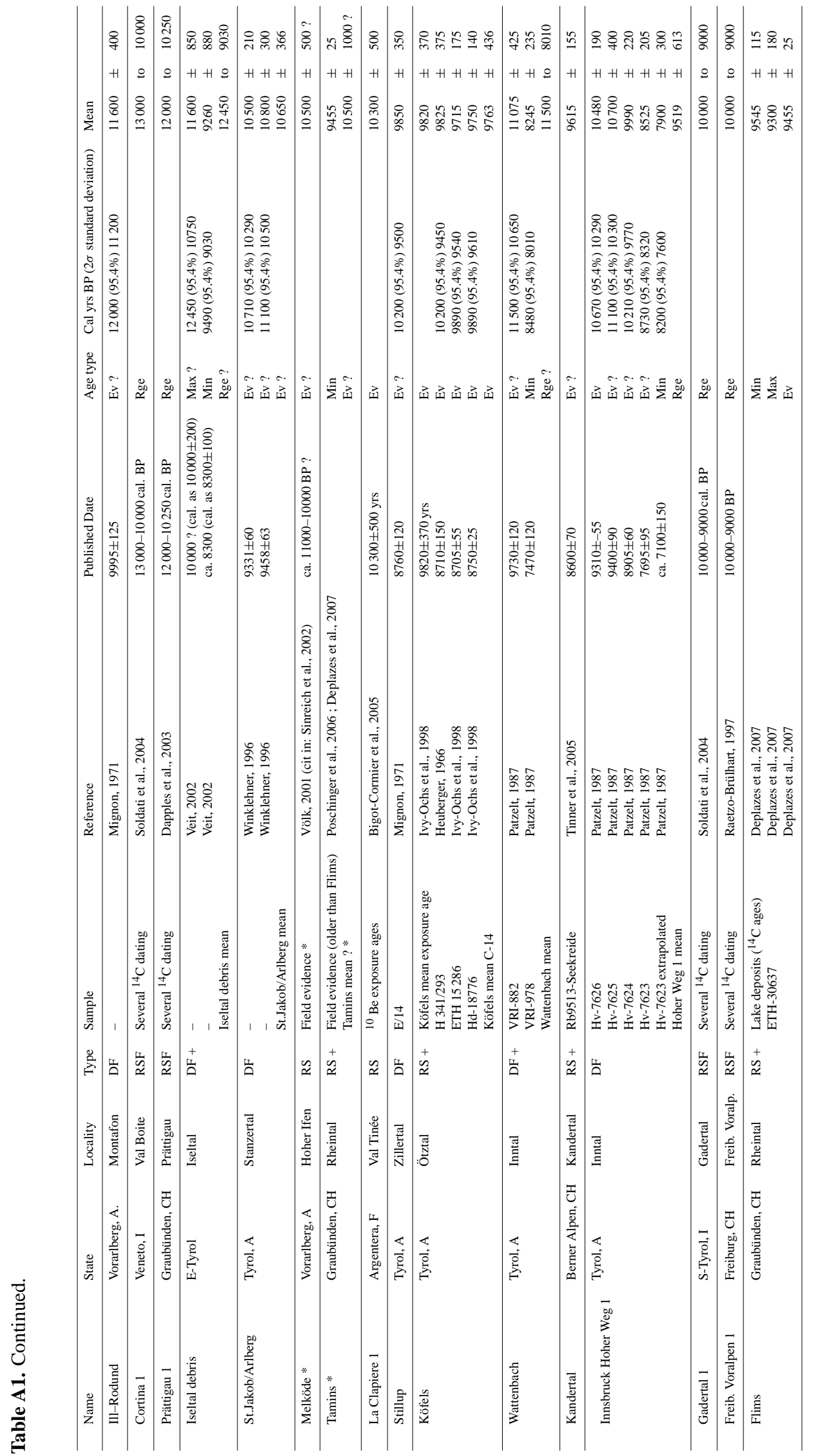




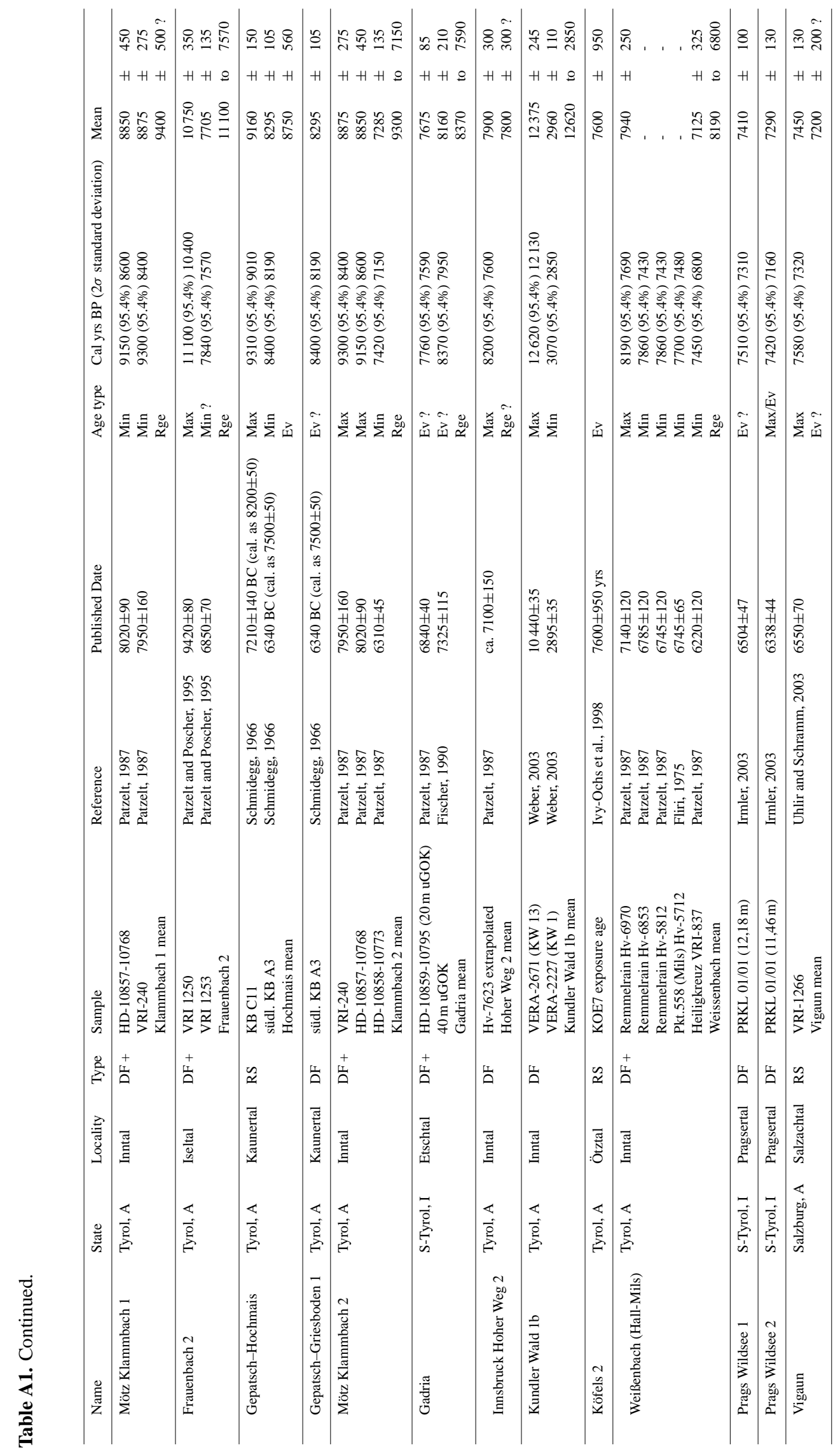









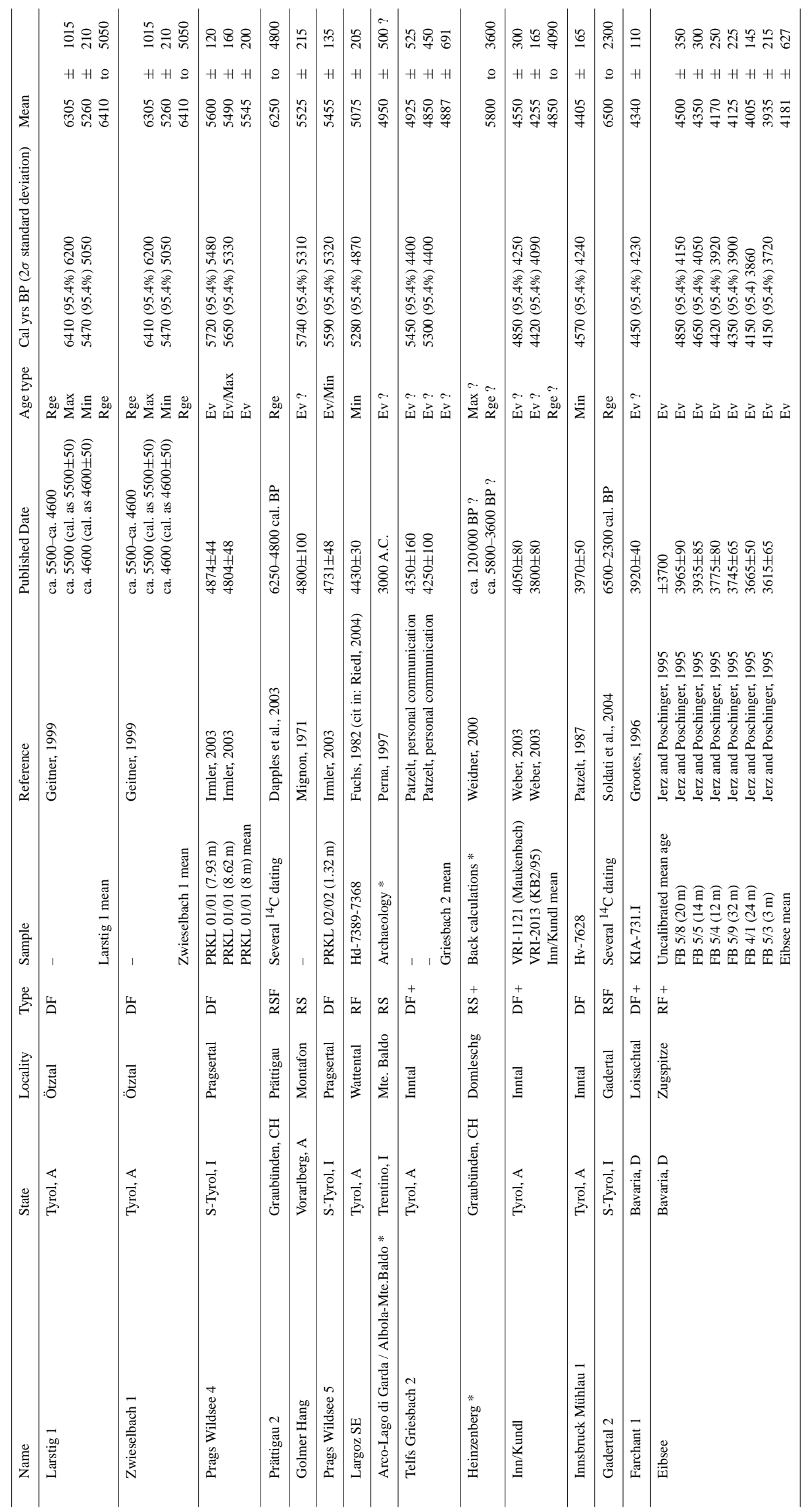




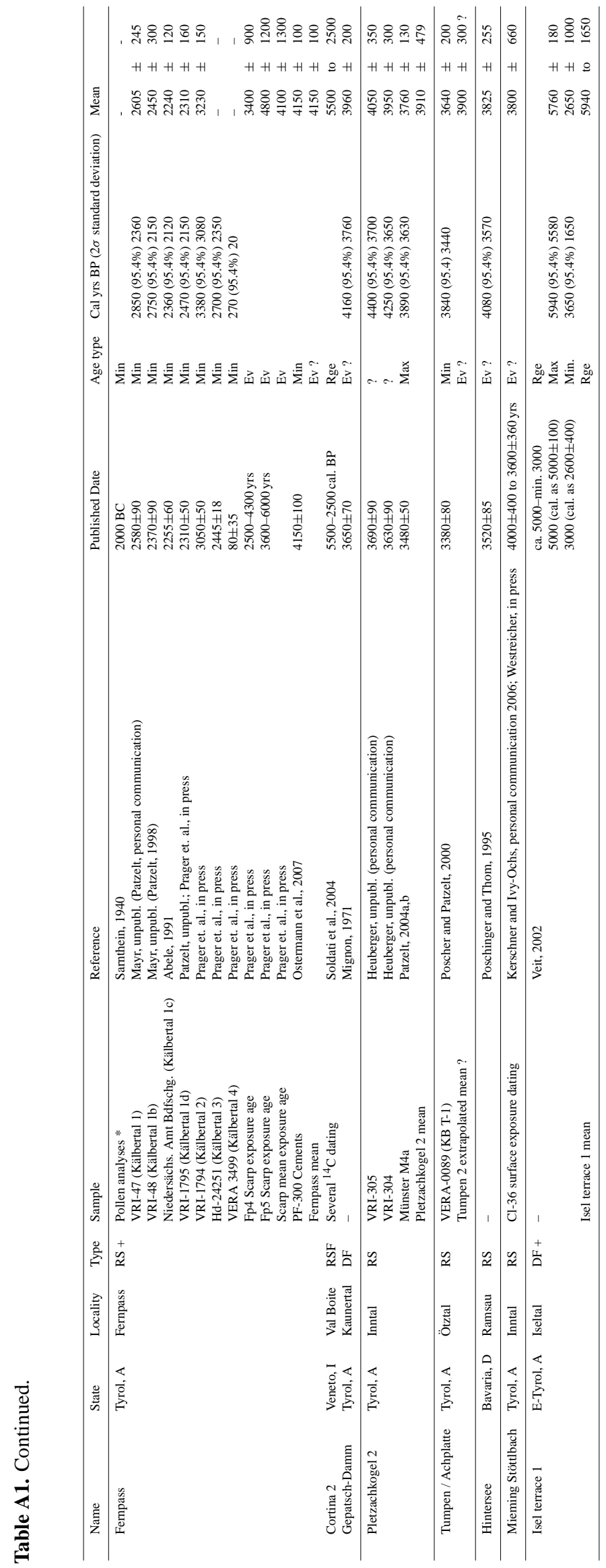









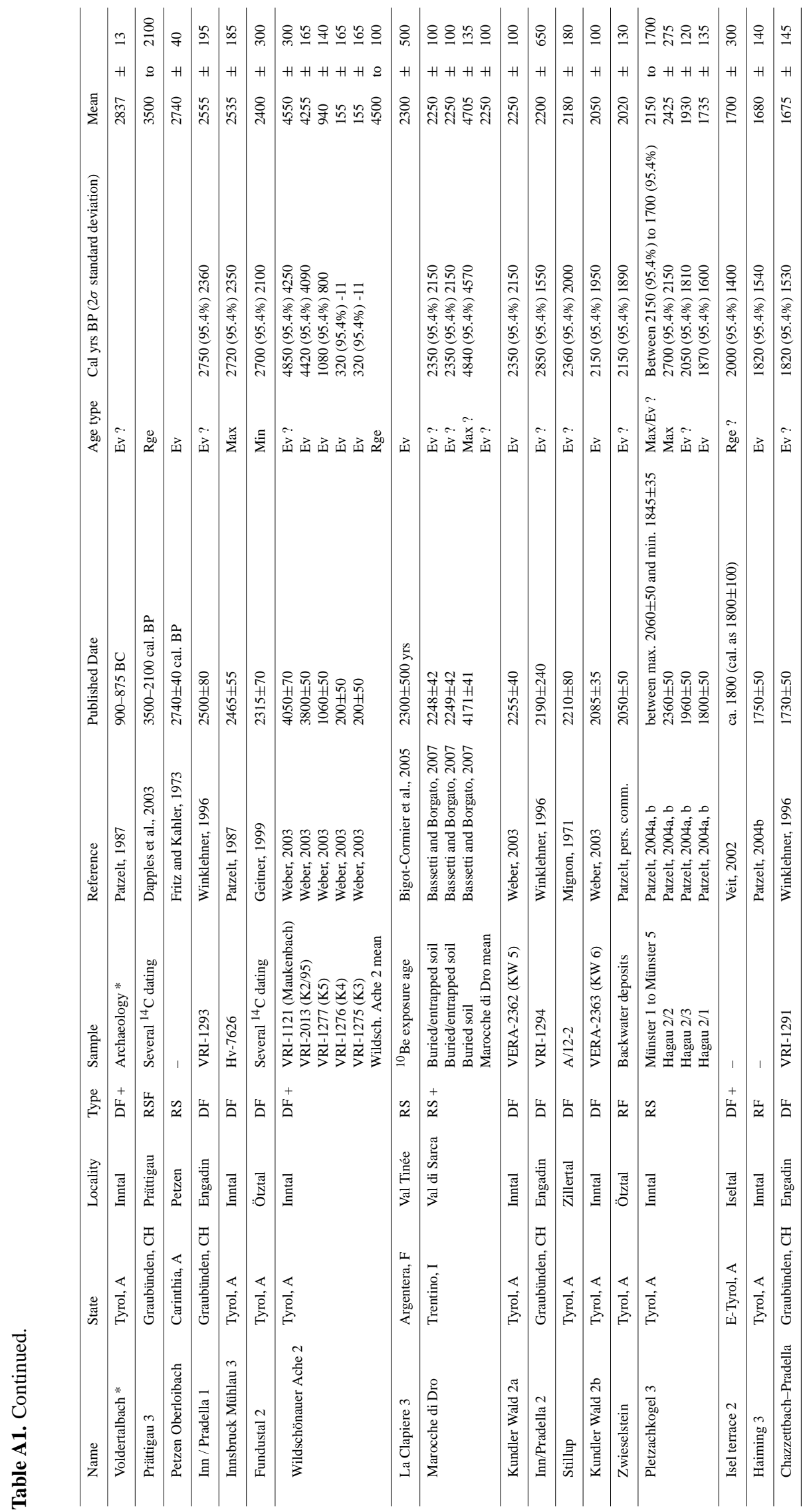




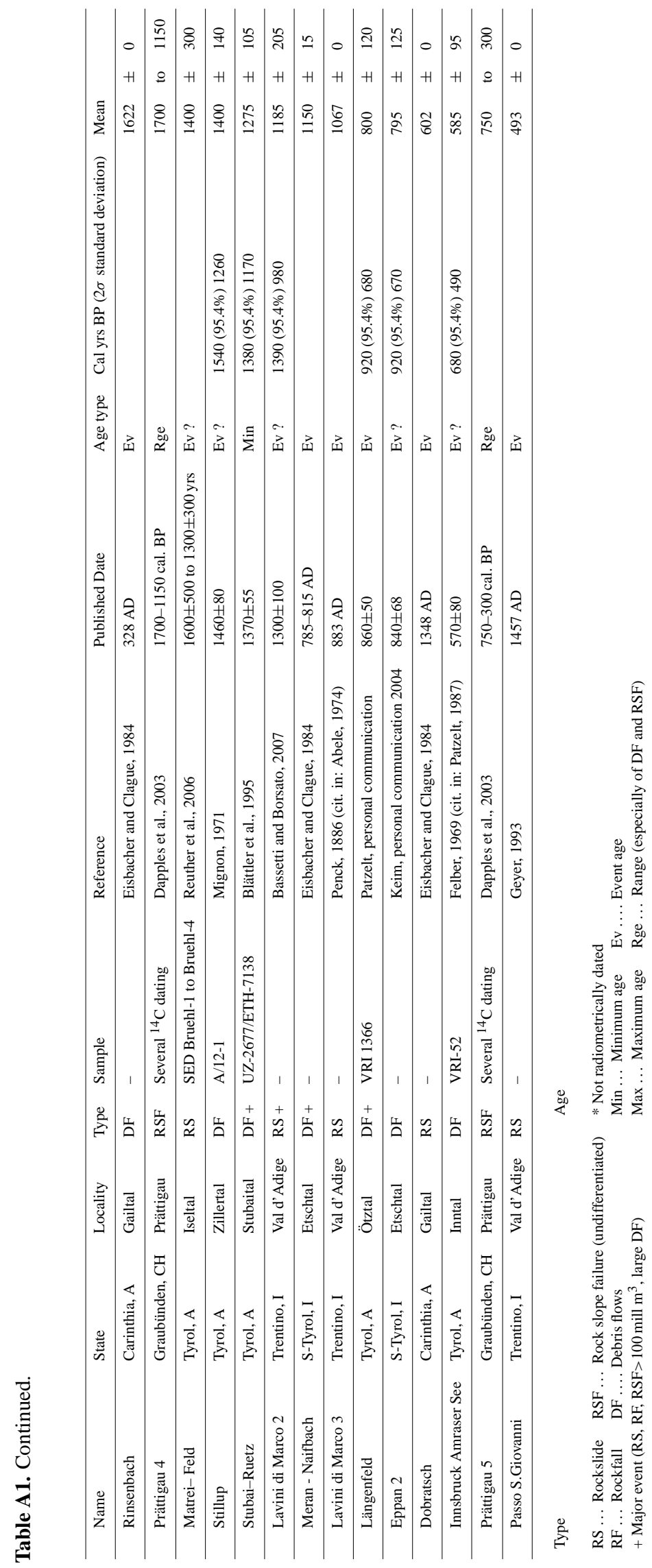


Acknowledgements. C. Spötl, H. Kerschner (both Univ. Innsbruck), A. Gruber (GBA) and G. Richter (ILF) are gratefully acknowledged for fruitful discussions, as is G. Duma (ZAMG Central Institute for Meteorology and Geodynamics, Vienna) for the provision of unpublished earthquake data. Financially this study was supported by ILF Consulting Engineers Ltd., TIWAG Tyrolean Hydroelectric Power Company Ltd., p+w Baugrund+Wasser Geo-ZT Ltd. and AlpECON Oeg. (all Tyrol, Austria).

Edited by: T. Glade

Reviewed by: M. Geertsema and another anonymous referee

\section{References}

Abele, G.: Die Fernpaßtalung und ihre morphologischen Probleme, Tübinger Geograph. Studien, 12, 1-123, 1964.

Abele, G.: Vom Eis geformte Bergsturzlandschaften, Zs. f. Geomorph. N. F., Suppl. 8, 119-147, 1969.

Abele, G.: Bergstürze in den Alpen. Ihre Verbreitung, Morphologie und Folgeerscheinungen, Wiss. Alpenvereinshefte, 25, 1-230, München, 1974.

Abele, G.: Der Fernpaßbergsturz - Eine differentielle Felsgleitung, Österr. Geograph. Ges., Zweigver. Innsbruck, Jhrber. 1989/1990, 22-32, 1991.

Abele, G.: Influence of glacier and climatic variation on rockslide activity in the Alps, In: Rapid mass movement as a source of climatic evidence for the Holocene, edited by: Matthews, J. A., Brunsden, B., Frenzel, B., Gläser, B., and Weiß, M. M., Paläoklimaforschung 19, Spec. Iss., ESF project "European palaeoclimate and man", 1-6, Fischer, 1997a.

Abele, G.: Rockslide movement supported by the mobilization of groundwater-saturated valley floor sediments, Zs. f. Geomorph. N. F., 41, 1-20, 1997 b.

Antognigni, M. and Volpers, R.: A late Pleistocene age for the Chironico rockslide (Central Alps, Ticono, Switzerland), Bull. Appl. Geol., 7/2, 113-125, 2002.

Atkinson, B. K.: Subcritical crack growth in geological materials, J. Geophys. Res., 89(B6), 4077-4114, 1984.

Atkinson, B. K.: Introduction to fracture mechanics and its geophysical applications, In: Fracture mechanics of rock, edited by Atkinson, B. K., 1-26, Academic Press, 1987.

Atkinson, B. K. and Meredith, P. G.: The theory of sub-critical crack growth with applications to minerals and rocks, In: Fracture mechanics of rock, edited by: Atkinson, B. K., 111-166, Academic Press, 1987.

Azzoni, A., Chiesa, S., Frassoni, A., and Govi, M.: The Val Pola landslide, Eng. Geology, 33, 59-70, 1992.

Ballantyne, C. K.: Paraglacial geomorphology, Quat. Sc. Rev., 21, 1935-2017, 2002.

Barton, N. and Choubey, V.: The shear strength of rock joints in theory and practice, Rock Mech. Rock Eng., 10, 1-54, 1977.

Bassetti, M. and Borsato, A.: Evoluzione geomorpholigica della Bassa Valle dell' Adige dall' Ultimo Massimo Glaciale: sintesi delle conoscenze e riferimenti ad aree limitrophe, Stud. Trent. Sci. Nat., Acta Geol., 82 (2005), 31-42, 2007.

Becker, A., Ferry, M., Monecke, K., Schnellmann, M., and Giardini, D.: Multiarchive paleoseismic record of late Pleistocene and
Holocene strong earthquakes in Switzerland, Tectonophysics, 400, 153-177, 2005.

Berrisford, M. A. and Matthews, J. A.: Phases of enhanced rapid mass movements and climatic variation during the Holocen: a synthesis, In: Matthews, J. A., Brunsden, B., Frenzel, B., Gläser, B., and Weiß, M. M., Rapid mass movement as a source of climatic evidence for the Holocene, Paläoklimaforschung, 19, 409440, Fischer, 1997.

Bertolini, G.: Radiocarbon dating on landslides in the Northern Apennines (Italy), In: Landslides and Climate Change, Challenges and Solutions, edited by McInnes, R., Jakeways, J., Fairbank, H., and Mathie, E., 73-80, Taylor and Francis, 2007.

Bertolini, G., Casagli N., Ermini, L., and Malaguti, C.: Radiocarbon Data on Lateglacial and Holocene Landslides in the Northern Apennines, Natural Hazards, 31, 645-662, 2004.

Bigot-Cormier, F., Braucher, R., Bourlès, D., Guglielmi, Y., Dubar, M., and Stéphan, J.-F.: Chronological constraints on processes leading to large active landslides, Earth and Planetary Science Letters, 235, 141-150, 2005.

Blättler, R., Hagedorn, H., Busche, D., and Baumhauer, R.: Sedimentary behavior of the alpine Ruetz River (Stubai Valley, Tyrol, Austria) in historical times, Z. Geomorph. N. F., Suppl. 100, 101-113, 1995.

Bonzanigo, L., Eberhardt, E., and Löw, S.: Measured response to a drainage adit in a deep creeping slide mass, In: Landslides, Research, Theory and Practice, Proc. 8th Internat. Symp. Landslides, Cardiff, Wales, 151-156, 2000.

Bortenschlager, S.: Beiträge zur Vegetationsgeschichte Tirols I. Inneres Ötztal und unteres Inntal, Berichte Naturwiss.Mediz. Vereins Innsbruck, 71, 19-56, 1984.

Brandner, R.: Geologische und Tektonische Übersichtskarte von Tirol, Tirol-Atlas, C1, C3, Univ.-Verlag Wagner, 1980.

Bronk Ramsey, C.: OxCal Version 3.10, www.rlaha.ox.ac.uk/orau/ oxcal.html, 2005.

Brückl E., Brückl, J., and Heuberger, H.: Present structure and prefailure topography of the giant rockslide of Köfels, Zs. Gletscherkde. Glazialgeol., 37, 49-79, 2001.

Brückl, E., Zangerl, C., and Tentschert, E.: Geometry and deformation mechanisms of a deep seated gravitational creep in cyrstalline rocks. In: ISRM Regional Symposium Eurock 2004, edited by: Schubert, W., 229-230, 2004.

Chernyshev, S. N. and Dearman, W. R.: Rock fractures, 272 pp., Butterworth-Heinemann, 1991.

Cossart, E., Braucher, R., Fort, M. Bourlés D. L., and Carcaillet J.: Slope instability in relation to glacial debuttressing in alpine areas (Upper Durance catchment, southeastern France): Evidence from field data and ${ }^{10} \mathrm{Be}$ cosmic ray exposure ages, Geomorphology, 95, 3-26, 2008.

Costa, J. E.: Nature, mechanics and mitigation of the Val Pola landslide, Valtellina, Italy, 1987-1988, Zs. f. Geomorphologie N.F., 35, 15-38, 1991.

Cruden, D. M.: A simple definition of a landslide, Bull. Int. Ass. Eng. Geol., 43, 27-29, 1991.

Cruden, D. M. and Varnes, D. J.: Landslide Types and Processes, In: Landslides: Investigation and Mitigation, edited by Turner, A. K. et al., Transportation Research Board Spec. Rep., 247, 3675, Nat. Res. Council, Washington, 1996.

Dapples, F., Lotter, A. F., Leeuwen, J. F. N. v., Knaap, W. O. v. d., Dimitriadis, S., and Oswald, D.: Paleolimnological evidence for 
increased landslide activity due to forest clearing and land-use since $3600 \mathrm{cal}$ BP in the western Swiss Alps, J. Paleolimnology, 27, 239-248, 2002.

Dapples, F., Oswald, D., Raetzo, H., Lardelli, T., and Zwahlen, P.: New records of Holocene landslide activity in the Western and Eastern Swiss Alps: Implication of climate and vegetation changes, Ecl. Geol. Helv., 96, 1-9, 2003.

Davies, M. C. R., Hamza, O., and Harris C.: The effect of Rise in Mean Annual Temperature on the Stability of Rock Slopes Containing Ice-Filled Discontinuities, Permafrost and Periglacial Proc., 12, 137-144, 2001.

Deplazes, G., Anselmetti, F. A., and Hajdas, I.: Lake sediments deposited on the Flims rockslide mass: the key to date the largest mass movement in the Alps, Terra Nova, 19, 252-258, 2007.

Drimmel, J.: Rezente Seismizität und Seismotektonik des Ostalpenraumes, In: Der geologische Aufbau Österreichs, edited by: Oberhauser, R., 507-527, Springer, 1980.

Eberhardt, E., Stead, D., and Coggan, J. S.: Numerical analysis of initiation and progressive failure in natural rock slopes - the 1991 Randa rockslide, Int. J. Rock Mechanics Mining Sc., 41, 69-87, 2004.

Eisbacher, G. and Clague, J. J.: Destructive mass movements in high mountain: hazard and management, Geol. Survey of Canada, Paper 84/16, 1-230, 1984.

Eisbacher, G. H., Linzer, H.-G., Meier, L., and Polinski, R.: A depth-extrapolated structural transect across the Northern Calcareous Alps of western Tyrol, Eclogae geol. Helv., 83, 711-725, 1990.

Eisbacher, G. H. and Brandner, R.: Role of high-angle faults during heteroaxial contraction, Inntal Thrust Sheet, Northern Calcareous Alps, Western Austria, Geol. Paläont. Mitt. Innsbruck, 20, 389-406, 1995.

Fischer, K.: Entwicklungsgeschichte der Murkegel im Vinschgau, Der Schlern, 64, 3-96, 1990.

Fliri, F.: Beiträge zur Geschichte der alpinen Würmvereisung: Forschungen am Bänderton von Baumkirchen (Inntal, Nordtirol), Zs. Geomorph. N.F., Suppl. 16, 1-14, 1973.

Fliri, F.: Das Inntal-Quartär im Westteil der Gnadenwaldterrasse, Innsbrucker Geograph. Stud., 2, 79-87, 1975.

Franke, A. and Gutdeutsch, R.: Eine makroskopische Auswertung des Nordtiroler Bebens bei Namlos am 8. Oktober 1930, Mitt. Erdbeben-Komm. N.F., 73, 1-11, 1973.

Fritz, A. and Kahler, F.: Ein Bergsturz am Nordfuß der Petzen (Nordkette der Karawanken), Carinthia II 163/83, 243-247, 1973.

Geertsema, M.: Landslides and historic climate in northern British Columbia, In: Landslides and Climate Change, Challenges and Solutions, edited by McInnes, R., Jakeways, J., Fairbank, H., and Mathie, E., 9-16, Taylor and Francis, 2007.

Geitner, C.: Sedimentologische und vegetationsgeschichtliche Untersuchungen an fluviatilen Sedimenten in den Hochlagern des Horlachtales (Stubaier Alpen/Tirol): ein Beitrag zur zeitlichen Differenzierung der fluvialen Dynamik im Holozän, Münchn. Geograph. Abh. B, 31, 1-247, 1999.

Geyer, O. F.: Die Südalpen zwischen Gardasee und Friaul: Trentino, Veronese, Vicentino, Bellunese, Sammlung geologischer Führer, 86, 1-576, Borntraeger Berlin, 1993.

Golas, B.: Der Eibseebergsturz, Eine geomorphologische Studie, Dipl. Thesis, 1-96, Univ. Innsbruck, 1996.
Grafenstein, U. v., Erlenkeuser, H., Müller, J., Jouzel, J., and Johnson, S.: The cold event 8200 years ago documented in oxygen isotope records of precipitation in Europe and Greenland, Clim. Dynam., 14, 73-81, 1998.

Grafenstein, U. V., Erlenkeuser, H., Brauer, A., Jouzel, J., Johnson, S. J.: A Mid-European Decadal Isotope-Climate Record from 15,000 to 5000 Years B.P., Science, 284, 1654-1657, 1999.

Grollimund, B. and Zoback, M. D.: Post glacial lithospheric flexure and induced stresses and pore pressure changes in the northern North Sea, Tectonophysics, 327, 61-81, 2000.

Grootes, P. M.: AMS ${ }^{14}$ C-Datierung der Proben Farchant 1 und 2, Unpubl. Report on behalf of Dr. J. Müller (TU München), 2 pp., Univ. Kiel, 1996.

Gross, D.: Bruchmechanik, 1-218, Springer Berlin, 1996.

Gruber, S. and Haeberli, W: Permafrost in steep bedrock slopes and its temperature-related destabilization following climate change, J. Geophys. Res., 112, F02S18, doi:10.1029/2006JF000547, 2007.

Gruner, U.: Bergstürze und Klima in den Alpen - gibt es Zusammenhänge? Bull. angew. Geol., 11, 25-34, 2006.

Grünthal, G., Musson, R. M. W., Schwarz, J., Stucchi, M.: European Macroseismic Scale 1998. Cahiers du Centre Européen de Geodynamique et de Seismologie, 15, Luxembourg, 1998 (www.gfz-potsdam.de/pb5/pb53/projekt/ems).

Gude, M. and Barsch, D.: Assessment of geomorphic hazards in connection with permafrost occurrence in the Zugspitze area (Bavarian Alps, Germany), Geomorphology, 66, 85-93, 2005.

Hendron, A. J. and Patton, F. D.: Vajont Slide - A Geotechnical Analysis Based on New Geologic Observations of the Failure Surface, Eng. Geol., 24, 475-491, 1987.

Hermanns, R. L., Blikra, L. H., Naumann, M., Nilsen, B., Panthi, K. K., Stromeyer, D., and. Longva, O.: Examples of multiple rockslope collapses from Köfels (Ötz valley, Austria) and western Norway, Eng. Geol., 83, 94-108, 2006.

Heuberger, H.: Gletschergeschichtliche Untersuchungen in den Zentralalpen zwischen Sellrain und Ötztal, Wiss. Alpenvereinshefte, 20, 1-126, Innsbruck, 1966.

Heuberger, H.: Das Ötztal. Bergstürze und alte Gletscherstände, kulturgeographische Gliederung, Innsbrucker Geograph. Stud., 2, 213-249, 1975.

Holzhauser, H., Magny, M., and Zumbühl, H. J.: Glacier and lakelevel variations in west-central Europe over the last 3500 years, The Holocene, 15, 789-801, 2005.

Hormes, A., Müller,B. U., and Schlüchter, C.: The Alps with little ice: evidence for eight Holocene phases of reduced glacier extent in the Central Swiss Alps, The Holocene, 11, 255-265, 2001.

Hübl, J.; Muren: Prozesse und Ablagerungsformen. Bedeutung für die Gefahrenzonenplanung, Ph.D. Thesis, 211 pp., Univ. Vienna, 1995.

Irmler, R.: Seesedimente als natürliches Archiv zur Erstellung eines Murkalenders am Beispiel des Pragser Wildsees (Norditalien), Ph.D. Thesis, 96 pp., Univ. Jena, 2003.

Ivy-Ochs, S., Heuberger, H., Kubik, P. W., Kerschner, H., Bonani, G., Frank, M., and Schlüchter, C.: The age of the Köfels event. Relative, ${ }^{14} \mathrm{C}$ and cosmogenic isotope dating of an early Holocene landslide in the Central Alps (Tyrol, Austria), Zs. Gletscherkd. Glazialgeol., 34, 57-68, 1998.

Ivy-Ochs, S., Kerschner, H., Kubik, P. W., and Schlüchter, C.: Glacier response in the European Alps to Heinrich event 1 cool- 
ing: the Gschnitz stadial, J. Quatern. Sc., 21, 115-130, 2005.

Jerz, H. and Poschinger, A. v.: Neueste Ergebnisse zum Bergsturz Eibsee-Grainau, Geol. Bavarica, 99, 383-398, 1995.

Jibson, R. W.: Use of landslides for paleoseismic analysis, Eng. Geol., 43, 291-323, 1996.

Keefer, D. K.: Landslides caused by earthquakes, Bull. Geol. Soc. America, 95, 406-421, 1984.

Kilburn, R. J. and Petley, D. N.: Forecasting giant, catastrophic slope collapse: lessons from Vajont, Northern Italy, Geomorphology, 54, 21-32, 2003.

Klebelsberg, R. v.: Das Nordalpenbeben vom 8. Oktober 1930, Mitt. Dt. u. Österr. Alpenverein, 12, 251-254, 1930.

Knauer, J.: Die geologischen Ergebnisse beim Bau der Bayerischen Zugspitz-Bahn, Abh. Geolog. Landesunters. Bayer. Oberbergamt, 10, 23-50, 1933.

Körner, H. and Ulrich, R.: Geologische und felsmechanische Untersuchungen für die Gipfelstation der Seilbahn Eibsee-Zugspitze, Geol. Bavarica, 55, 407-421, 1965.

Kraus, E.: Die Seismotektonik der Tiroler Alpen, Sonderdruck aus Gerlands Beiträge zur Geophysik, 30, 96-135, 1931.

Lenhardt, W., Freudenthaler C., Lippitsch, R., and Fiegweil, E.: Focal-depth distribution in the Austrian Eastern Alps based on macroseismic data, Austrian J. Earth Sc., 100, 66-79, 2007.

Löw, S., Ebneter, F., Bremen, R., Herfort, M., Lützenkirchen, V., and Matousek, F.: Annual Opening and Closure of Alpine Valleys, Felsbau, 25, 60-65, 2007.

Madritsch, H.: Geologie und Hydrogeologie von Grosshangbewegungen im Innsbrucker Quarzphyllit und ihre wasserwirtschaftliche Bedeutung, vorderes Wattental, Tirol, Dipl. Thesis, 178 pp., Univ. Innsbruck, 2004.

Matthews, J. A., Brunsden, B., Frenzel, B., Gläser, B., and Weiß, M. M.: Rapid mass movement as a source of climatic evidence for the Holocene, Paläoklimaforschung, 19, 444 pp., Fischer, 1997.

Mignon, K.: Datierung von Holzfunden in Talverschüttungen im Montafon, Kaunertal und Zillertal, Zs. Gletscherkde. Glazialgeol., 7, 215-21, 1971.

Monecke, K., Anselmetti, F. S., Becker, A., Schnellmann, M., Sturm, M., and Giardini, D.: Earthquake-induced deformation structures in lake deposits: A Late Pleistocene to Holocene paleoseismic record for Central Switzerland, Ecl. Geol. Helv., 99, 343-362, 2006.

Nicolussi, K.: Die Bauhölzer der Via Claudia Augusta bei Lermoos (Tirol), In: Via Claudia - Neue Forschungen, edited by Walde, E., Inst. f. Klassische Archäologie, Univ. Innsbruck, 113-145, 1998.

Nicolussi, K. and Patzelt, G.: Discovery of early-Holocene wood and peat on the forefield of the Pasterze Glacier, Eastern Alps, Austria, The Holocene, 10, 191-199, 2000.

Nicolussi, K. and Patzelt, G.: Untersuchungen zur Holozänen Gletscherentwicklung von Pasterze und Gepatschferner (Ostalpen), Zs. Gletscherkde. Glazialgeol., 36, 1-87, 2001.

Oeggl, K.: Palynologische Untersuchungen aus dem Bereich des römischen Bohlenweges bei Lermoos, Tirol, In: Via Claudia - Neue Forschungen, edited by Walde, E., Inst. f. Klassische Archäologie, Univ. Innsbruck, 147-171, 1998.

ÖNORM B 4015: Belastungsannahmen im Bauwesen Außergewöhnliche Einwirkungen - Erdbebeneinwirkungen, Grundlagen und Berechnungsverfahren, Österr. Normungsinstitut, 61 pp., Wien, 2007.
Ostermann, M., Sanders, D., Prager, C., and Kramers, J.: Aragonite and calcite cementation in "boulder-controlled" meteoric environments on the Fern Pass rockslide (Austria): implications for radiometric age-dating of catastrophic mass movements, Facies, 53, 189-208, 2007.

Pagliarini, L.: Lithostratigraphie und Strukturgeologie der Massenbewegungen des westlichen Tschirgant-Massivs, Dipl. Thesis, Univ. Innsbruck, in preparation, 2008.

Patzelt, G.: Die spätglazialen Stadien und postglazialen Schwankungen von Ostalpengletschern, Ber. D. Dt. Bot. Ges., 85, 47-57, 1972.

Patzelt, G.: Der zeitliche Ablauf und das Ausmass postglazialer Klimaschwankungen in den Alpen, In: Dendrochronologie und postglaziale Klimaschwankungen in Europa, edited by Frenzel, B., 248-259, Steiner, Wiesbaden, 1977.

Patzelt, G.: Radiocarbondatierung Murschuttkegel Telfs, Unpubl. Report on behalf of Amt f. Wildbach- u. Lawinenverbauung, Innsbruck, 1982.

Patzelt, G.: Untersuchungen zur nacheiszeitlichen Schwemmkegelund Talentwicklung in Tirol, Veröff. Mus. Ferdinandeum Innsbruck, 67, 93-123, 1987.

Patzelt, G.: Arbeitsbereich Naturraumforschung - Untersuchungen zur nacheiszeitlichen Talentwicklung, Bergstürze, In: Inst. f. Hochgebirgsforschung: Jahresbericht 1997, 9-13, Institut für Hochgebirgsforschung, Univ. Innsbruck, 1998.

Patzelt, G.: Arbeitsbereich Naturraumforschung - Untersuchungen zur nacheiszeitlichen Talentwicklung, Bergstürze, In: Inst f. Hochgebirgsforschung, Jahresbericht 1998, 9-10, Univ. Innsbruck, 1999.

Patzelt, G.: Tschirgant-Haiming-Pletzachkogel. Datierte Bergsturzereignisse im Inntal und ihre talgeschichtlichen Folgen, Presentation, alpS Symposium Naturgefahren Management 13.10.2004, Galtür, 2004a.

Patzelt, G.: Die Bergstürze vom Pletzachkogel bei Kramsach und ihre talgeschichtlichen Folgen, Presentation, Geokolloquium 11.03.2004, Inst. of Geology and Paleontology, Univ. Innsbruck, 2004b.

Patzelt, G.: Die nacheiszeitliche Temperaturentwicklung im Ostalpenraum, abgeleitet aus Baumgrenz- und Gletscherschwankungen, Manuscript, Inst. f. Hochgebirgsforschung, Univ. Innsbruck, 2005.

Patzelt, G. and Bortenschlager, S.: Die postglazialen Gletscher- und Klimaschwankungen in der Venedigergruppe (Hohe Tauern, Ostalpen), Zs. f. Geomorph. N. F., Suppl. 16, 25-72, 1973.

Patzelt, G. and Poscher, G.: Der Tschirgant-Bergsturz, Arbeitstagung 1993 Geol. B.-A., Geologie des Oberinntaler Raumes Schwerpunkt Blatt 144 Landeck, Exkursion D: Bemerkenswerte Geologische und Quartärgeologische Punkte im Oberinntal und aus dem äußerem Ötztal, 206-213, 1993.

Patzelt, G. and Poscher, G.: Neue Ergebnisse zur Quartärgeologie Osttirols: Fazies und Sedimentationsgeschichte des FrauenbachSchwemmfächers bei Lavant, Arbeitstagung 1995 Geol. B.-A., Geologie von Osttirol, 67-73, 1995.

Perna, G.: Itinerari geologici: La valle delle Marocche (seconda parte), Econ. Trentina, 2, 95-122, 1997.

Poscher, G. and Patzelt, G.: Sink-hole Collapses in Soft Rocks, Felsbau, Rock and Soil Eng., 18, 36-40, 2000.

Poschinger, A. v.: Large rockslides in the Alps: A commentary on the contribution of G.Abele (1937-1994) and a review of some 
recent developments, In: Catastrophic Landslides: Effects, Occurrence, and Mechanisms, edited by Evans, S. G. and DeGraff, J. V., Rev. Eng. Geol., 15, 237-255, Geol. Soc. Am., 2002.

Poschinger, A. v. and Thom, P.: Neue Untersuchungen am Bergsturz Hintersee-Ramsau (Berchtesgadener Land), Geol. Bavarica, 99, 399-411, 1995.

Poschinger, A. v., Wassmer, P., and Maisch, M.: The Flims Rockslide: History of Interpretation and new Insights, In: Massive Rock Slope Failures, edited by Evans, S. G., ScarasciaMugnozza, G., Strom, A., and Hermanns, R. L., 341-369, Kluwer Academic Publ., Dordrecht, 2006.

Prager, C., Patzelt, G., Ostermann, M., Ivy-Ochs, S., Duma, G., Brandner, R., and Zangerl, C.: The age of the Fernpass rockslide (Tyrol, Austria) and its relation to dated mass movements in the surroundings, Pangeo Austria 2006, Innsbruck Univ. Press Conf. Series, 258-259, 2006a.

Prager, C., Krainer, K., Seidl, V., and Chwatal, W.: Spatial features of Holocene Sturzstrom-deposits inferred from subsurface investigations (Fernpass rockslide, Tyrol, Austria), Geo.Alp, 3, 147-166, 2006b.

Prager, C., Zangerl, C., Brandner, R., Krainer, K., and Chwatal, W.: Structure and kinematics of a long run-out rockslide: the Holocene Fernpass Sturzstrom (Northern Calcareous Alps, Tyrol, Austria), Pangeo Austria 2006, Innsbruck Univ. Press Conf. Series, 260-261, 2006c.

Prager, C., Zangerl, C., Brandner, R., and Patzelt, G.: Increased rockslide activity in the Middle Holocene? New evidences from the Tyrolean Alps (Austria), In: Landslides and Climate Change, Challenges and Solutions, edited by McInnes, R., Jakeways, J., Fairbank, H., and Mathie, E., 25-34, Taylor and Francis, 2007.

Prager, C., Ivy-Ochs, S., Ostermann, M., Synal, H.-A-, and Patzelt, G.: Geology and radiometric ${ }^{14} \mathrm{C}-,{ }^{36} \mathrm{Cl}-$ and Th-/U-dating of the Fernpass rockslide (Tyrol, Austria), Geomorphology, Spec. Iss., Large slope instabilities: from dating, triggering and evolution modelling to hazard assessment, in press, 2008.

Raetzo-Brülhart, H.: Massenbewegungen im Gurnigelflysch und Einfluss der Klimaänderung, Arb.-Ber. NFP, 31, 256 pp., ETH Zürich, 1997.

Raetzo, H. and Lateltin, O.: Mass movements: landslides, blockfalls and rock avalanches, In: OcCC Organe consultatif sur le changements climatiques / Beratendes Organ für Fragen der Klimaänderung, Report Extreme Events and Climate Change, 73-76, Bern, 2003 (www.occc.ch/reports/Extremereignisse03/ PDF_D/9-00.pdf).

Reiter, F., Ortner, H., and Brandner, R.: Seismically active Inntal fault zone: inverted European rift structures control upper plate deformation, Mem. Soc. Geol. Italiana, 54, 233-234, 2003.

Renard, F., Gratier, J.-P., and Jamveit, B.: Kinetics of crack-sealing, intergranular pressure solution, and compaction around active faults, J. Struct. Geology, 22, 1395-1407, 2000.

Reuther, A. U., Reitner, J. M., Ivy-Ochs, S., Kubik, P. W., and Herbst, P.: From kinematics to dating - the Sturzstrom deposit of Feld (Matrei/Eastern Tyrol/Austria), Geophys. Res. Abstr. 8, 04947, EGU 2006 (www.geologie.ac.at/pdf/Poster/Poster_ EGU2006_sturzstrom.pdf).

Riedl, F.: Instabile Hangflanken und deren Auswirkung auf bautechnische Anlagen, Dipl. Thesis, 130 pp., Univ. Innsbruck, 2004.

Sarnthein, R. v.: Moor- und Seeablagerungen aus den Tiroler
Alpen und ihre waldgeschichtliche Bedeutung. II. Teil: Seen der Nordtiroler Kalkalpen, Beih. Botan. Centralblatt, LX Abt. B 3, 437-492, 1940.

Sartori, M., Baillifard. F., Jaboyedoff, M., and Rouiller, J.-D.: Kinematics of the 1991 Randa rockslides (Valais, Switzerland), Natural Hazards Earth System Sc., 423-433, 2003.

Schmid, S. M., Fügenschuh, B., Kissling, E., and Schuster, R.: Tectonic map and overall architecture of the Alpine orogen, Eclogae geol. Helv., 97, 93-117, 2004.

Schmidegg, O.: Bericht Staudamm Gepatsch, Geologie im Speicherbecken (Geologische Grundlagen für die Hangbewegungen), Unpubl. Report, K13-392, TIWAG Innsbruck, 1966.

Schorn, J.: Bericht über das Erdbeben in den Alpen vom 13.Juli 1910, Mitt. d. Erdbeben-Kommission N. F., 42, 1-77, Akad. d. Wiss., 1911.

Schorn, J.: Die Erdbeben in Tirol und Vorarlberg in den 1916-1921, Amtl. Veröffentl. ZA. f. Meteorologie u. Geodynamik, 13, 2640, 1922.

Seijmonsbergen, A. C., Woning, M. P., Verhoef, P. N. W., and de Graaff, L. W. S.: The failure mechanism of a Late Glacial Sturzstrom in the Subalpine Molasse (Leckner Valley, Vorarlberg, Austria), Geomorphology, 66, 277-286, 2005.

Sinreich, M., Goldscheider, N., and Hötzl, H.: Hydrogeologie einer alpinen Bergsturzmasse (Schwarzwassertal, Vorarlberg), Beitr. Hydrogeol., 53, 5-20, 2002.

Soldati, M., Corsini, A., and Pasuto, A.: Landslides and climate change in the Italian Dolomites since the Late Glacial, Catena, 55, 141-161, 2004.

Strasser, M., Anselmetti, F. S., Fäh, D., Giardini, D., and Schnellmann, M.: Magnitudes and source areas of large prehistoric northern Alpine earthquakes revealed by slope failures in lakes, Geology, 34, 1005-1008, 2006.

Tentschert, E.: Das Langzeitverhalten der Sackungshänge im Speicher Gepatsch (Tirol, Österreich), Felsbau, 16, 194-200, 1998.

Tinner, W., Kaltenrieder, P., Soom, M., Zwahlen, P., Schmidhalter, M., Boschetti, A., and Schlüchter, C.: Der nacheiszeitliche Bergsturz im Kandertal (Schweiz): Alter und Auswirkungen auf die damalige Umwelt, Eclogae geol. Helv., 98, 83-95, 2005.

Tucker, M. E. and Wright, V. P.: Carbonate Sedimentology, Blackwell Sc. Publ., 482 pp., Oxford, 1990.

Uhlir, C. F. and Schramm, J.: Zur Kinematik des Bergsturzes von Vigaun (Salzburg), Mitt. ÖGG, 93, 161-173, 2003.

USGS/NEIC: U.S. Geological Survey/National Earthquake Information Center, Earthquake Database PDE (1973 - Present), Computer file, www. neic.usgs.gov, 2005.

Van Husen, D., Ivy-Ochs, S., and Alfimov, V.: Landslides in Almtal. Mechanism and Age, Austrian J. Earth Sc., 100, 114-126, 2007a.

Van Husen, D. and Fritsch, A.: Der Bergsturz von Wildalpen (Steiermark), Jb. Geol. B.-A., 147, 201-213, 2007b.

Veit, H.: Die Alpen: Geoökologie und Landschaftsentwicklung, Ulmer, 352 pp., Stuttgart, 2002.

Vidal, H.: Neue Ergebnisse zur Stratigraphie und Tektonik des nordwestlichen Wettersteingebirges und seines nördlichen Vorlandes, Geol. Bavarica, 17, 56-88, 1953.

Vidrih, R., Ribicic, M, and Suhadolc, P.: Seismogeological effects on rocks during the 12 April 1998 upper Soca Territory earthquake (NW Slovenia), Tectonophysics, 330, 153-175, 2001.

Weber, A.: Geomorphologische Untersuchungen im Raum Kundl, Eine chronologische Darstellung der spät- und nacheiszeitlichen 
Schwemmkegel- und Talentwicklung unter Einbeziehung der prähistorischen Funde aus der Schottergrube Wimpissinger, Dipl. Thesis, 1-107, Univ. Innsbruck, 2003.

Weidner, S.: Kinematik und Mechanismus tiefgreifender alpiner Hangdeformationen unter besonderer Berücksichtigung der hydrogeologischen Verhältnisse, Ph.D. Thesis, 257 pp., Univ. Erlangen-Nürnberg, 2000.

Weirich, J. and Bortenschlager, S.: Beiträge zur Vegetationsgeschichte Tirols III: Stubaier Alpen - Zillertaler Alpen, Berichte naturwiss.-mediz. Vereins Innsbruck, 67, 7-30, 1980.

Westreicher, F.: Der Holozäne Bergsturz am Stöttlbach, Mieminger Plateau (Tirol), Dipl. Thesis, Univ. Innsbruck, 2008 (in press).

Winklehner, B.: Quartäre Ablagerungen und Prozesse im oberen Inntal, Stanzer- und Paznauntal und deren geotechnische Bedeutung (Tirol/Engadin), Dipl. Thesis, 111 pp., Univ. Innsbruck, 1996.

ZAMG: Earthquakes in Austria, Computer file, www.zamg.ac.at, 2005a.

ZAMG: Austrian earthquake catalogue, Earthquakes in the Fernpass-region, Computer file (as at 18.05.2005), Vienna, $2005 b$.
Zanchetta, G., Drysdale, R. N., Hellstrom, J. C., Fallick, A. E., Isola, I., Gagan, M. K., and Pareschi, M. T.: Enhanced rainfall in the Western Mediterranean during deposition of sapropel S1: stalagmite evidence from Corchia cave (Central Italy), Quat. Sc. Rev., 26, 279-286, 2007.

Zangerl, C.: Analysis of Surface Subsidence in Crystalline Rocks above the Gotthard Highway Tunnel (Switzerland), Ph. Thesis, 208 pp., ETH Zürich, 2003.

Zangerl, C., Eberhardt, E., Schönlaub, H., and Anegg, J.: Deformation behaviour of deep-seated rockslides in crystalline rock, In: Proceeding of the 1st Canada - US Rock Mechanics Symposium, Vancouver, Canada, 901-908, 2007.

Zangerl, C, Prager, C, Chwatal, W., Mertl, S., Renk, D., SchneiderMuntau, B., Eberhardt, E., Kirschner, H., Brandner, R., Brückl, E., Fellin, W., Tentschert, E., Eder, S., Poscher, G., and Schönlaub, H.: Process-based investigations and monitoring of deep-seated landslides, In: Contributions to a sustainable natural hazard management, edited by Stötter, J., Weck-Hannemann, H., and Veulliet, E., Springer, in press, 2008. 